Article

\title{
What Effects Could Global Value Chain and Digital Infrastructure Development Policies Have on Poverty and Inequality after COVID-19? ${ }^{\dagger}$
}

\author{
Ximena del Carpio ${ }^{1}$, José A. Cuesta ${ }^{1}$, Maurice D. Kugler ${ }^{2, * \mathbb{D}}$, Gustavo Hernández ${ }^{3}$ and Gabriel Piraquive $^{3}$ \\ 1 World Bank, Washington, DC 20433, USA; xdelcarpio@worldbank.org (X.d.C.); \\ jcuesta@worldbank.org (J.A.C.) \\ 2 Center for Micro-Economic Policy Research (CMEPR), Schar School of Policy and Government, \\ George Mason University, Arlington, VA 22201, USA \\ 3 Departamento Nacional de Planeación, División de Estudios Especiales, Santafé de Bogotá, Colombia; \\ ghernandez@dnp.gov.co (G.H.); gpiraquive@dnp.gov.co (G.P.) \\ * Correspondence: mkugler@gmu.edu \\ + We appreciate insights and comments from three anonymous referees, Ricardo Bonilla, Maria Eugenia \\ Davalos, Dario Maldonado, Hernan Winkler, and participants in the Misión de Empleo de la República de \\ Colombia workshop in November 2020 as well as thank research and data support from the World Bank and \\ Government of Colombia's Departamento Nacional de Planeación, and research assistance from Carmen \\ Delgado, Julieth Pico and Nicolas Ramírez. The positions expressed in this paper do not represent the views \\ of the World Bank, its Board of Directors, its member states, or of the Government of Colombia.
}

Citation: del Carpio, Ximena, José A. Cuesta, Maurice D. Kugler, Gustavo Hernández, and Gabriel Piraquive. 2022. What Effects Could Global Value Chain and Digital Infrastructure Development Policies Have on Poverty and Inequality after COVID-19? Journal of Risk and

Financial Management 15: 43 https://doi.org/10.3390/ jrfm15020043

Academic Editor: Thanasis Stengos

Received: 24 May 2021

Accepted: 1 January 2022

Published: 19 January 2022

Publisher's Note: MDPI stays neutral with regard to jurisdictional claims in published maps and institutional affiliations.

Copyright: (C) 2022 by the authors. Licensee MDPI, Basel, Switzerland. This article is an open access article distributed under the terms and conditions of the Creative Commons Attribution (CC BY) license (https:// creativecommons.org/licenses/by/ $4.0 /)$.

\begin{abstract}
It is clear that in the transition out of the COVID-19 crisis in Colombia there will be great need for formal job creation. One source that has been widely discussed in policy circles is strengthening linkages of Colombian firms with Global Value Chains (GVCs). Another source that has received recent attention, and deservedly so, is digital infrastructure development (DID)—which can boost telework and virtual human capital accumulation. Reduction in poverty and inequality through more and better formal employment is an important aspect of a jobs and economic transformation (JET) agenda. In this paper, we explore-through a computable general equilibrium model (CGE) and a microsimulation framework - to what extent reforms of the type envisioned in the JET agenda and which could generate GVC linkages, as well as through DID, for Colombia, and we project their impact on poverty and inequality up to 2030. Our findings show limited impact of the three types of policy changes considered for GVCs—namely (i) fall in barriers for seamless business logistics, (ii) reductions in tariffs, and (iii) lower barriers to foreign direct investment (FDI). The impact of DID on inequality is also moot. There is however a modest impact on poverty reduction in the combined policy of digital infrastructure with a boost in skilled labor. This finding can be linked to different factors. First, there are relatively few direct jobs created to benefit households with low levels of human capital. Second, there might be indirect job creation through backward linkages to local suppliers by firms linked to GVCs, but this effect would be a general equilibrium effect that our CGE model with a partial equilibrium microsimulation distributional module does not fully capture. Third, the positioning of Colombian firms to latch onto GVCs, and also generate demand for local intermediate inputs and services, is not optimal. Fourth, DID may generate more general labor market opportunities through telework and virtual learning expansions but could also induce larger wage gaps as the skill premium rises so that the net effect on inequality is ambiguous.
\end{abstract}

Keywords: COVID-19 pandemic; aggregate supply and demand shocks; income fall; poverty; inequality; JET; GVCs; productivity; formal employment; wages; CGE; microsimulations

JEL Classification: F14; J23; J24; J63; L86; O15; O33 


\section{Introduction}

It is well understood that job creation has a crucial role so that economic growth translates to better outcomes in key areas of human well-being as highlighted in the World Development Report (World Bank 2013). In particular, jobs are beneficial both for workers who engage in productive economic activity and for firms that are more efficient with stable employee attachment. In addition, there are social benefits from reduced idleness (which arises from both unemployment and underemployment) as resource allocation is further directed to production and away from unproductive or even destructive activities (e.g., crime and anti-social behavior).

In particular, fostering formal employment growth-as proposed by a jobs and economic transformation (JET) agenda advanced by World Bank Group (2019)—can enhance welfare by tipping the balance towards less precarious informal employment (as is prevalent in Colombia and other developing countries in agriculture and other sectors) to more stable and productive formal jobs (more frequent in manufacturing and services). The vulnerability associated with having more than half of the workforce in the informal sector is being laid bare by how COVID-19 lockdowns have exacted a toll on workers unable earn a living and with scant access to social security safety nets. Those informal workers, and others in manual (including hospitality services) occupations, in contrast with employees in the modern sector, have jobs on the wrong side of the digital divide-which are not amenable to telework and do not have provisions for health-related benefits.

Among the workers exposed by COVID-19 to substantial earning capacity losses, there are some from chronically poor households with structural impediments to earning an income that provides a living standard above the poverty line. A key aspect of a JET agenda, in addition to labor productivity growth and higher wages, would be the higher well-being brought about by job stability, breaking painful "feast or famine" cycles brought about by ongoing volatility. If households can benefit from more steady income sources, they are better off, and formal jobs generally enhance stability through a dependable salary stream.

An idea to foster modern employment that has been discussed extensively in Colombia is to implement policies that promote formal job creation through the integration of national firms into global value chains (GVCs). Those households whose members can access the more desirable jobs can be beneficiaries from a JET agenda. There are key questions about this process in connection with the goals of eradicating extreme poverty and boosting shared prosperity:

(i) Which households can access the formal jobs created by firms in the GVC-JET process?

(ii) What are the characteristics of households that do not benefit from the new JET jobs?

(iii) What is the effect on poverty and inequality of formal employment growth through JET?

If there is indeed a substantial share of households among vulnerable populations who can switch from informal to formal sector employment, there can be a significant reduction in both poverty and inequality. This is crucial as the benefits and costs of the COVID19 lockdown have been very unevenly distributed in Colombia, as in many developing countries. The benefits of lockdown policies have accrued to households with older and relatively more affluent individuals. The costs of the lockdown have mostly been borne by workers on the wrong side of the digital divide-those who are unable to telework and have lost income-generation capacity disproportionately. It is now recognized that limitations in digital infrastructure development (DID) can hinder the opportunity for many workers to shield from the pandemic shock via remote employment as poor telecommunications have been a bottleneck to telework-and retraining via remote learning.

Therefore, any post-COVID-19 labor market policies and JET reforms must aim to help poor and vulnerable households suffering from job displacement and earnings losses to gain formal employment and higher wages to move above poverty-trap threshold income levels. This process may involve many stages and, apart from boosting labor demand through expansion of the export sector, may also require human capital accumulation opportunities, 
both in general purpose skills and specific to relevant sectors and occupations, for the most disadvantaged households.

For a job to be transformative it must lead to increased labor productivity, good working conditions, and stabilizing social protection. Technological change, reforms, global economic shocks, and demographic transitions all may shift the composition and nature of the demand of new jobs. Job diagnostics help inform us about how widespread job creation will need to be and the extent of productivity and income gains that will result from new and different jobs. To this economic transformation capacity of reforms, policies, or shocks, we need to add its distributional and poverty-reduction impacts, and pose questions such as:

- Which population groups are likely to benefit from the vacancies generated by the new labor demands-direct and indirect?

- More specifically, which households access the better jobs created by firms as the structural transformation process evolves?

- What are the constraints for households that do not benefit from the JET jobs?

We provide a clear framework of analysis to address the above questions. The equity considerations--static as discussed here but also more generally intertemporal and intergenerational in nature--need to be explicitly analyzed. In order to do so, we develop an analytical model that brings together labor demand and supply, on the one hand, and builds in an equity lens in a JET agenda proposed here-to generate job opportunities through GVC integration in the context of the COVID-19 shock, on the other hand. One important aspect of the COVID-19 disruption is that many global supply chains will need to be reconfigured now, due to ripple effects from the initial supply shocks and subsequent demand shocks, that generated prolonged closures as well as shutdowns across production facilities in different countries.

As the COVID-19 crisis subsides, there will be need for new global suppliers to emerge. This could well create a window of opportunity for newcomers, including Colombian firms, to latch into GVCs by becoming reliable providers of intermediate inputs and services, as well as key components of final products assembled elsewhere. Those firms could create formal jobs for workers in the mid-range of the human capital distribution, as they will operate relatively sophisticated technologies. Additionally, jobs could be created for workers in the lower-end of the skill distribution. The latter could happen if the Colombian firms linked to GVCs generate backward linkages by demanding, from local suppliers, intermediate inputs and services, effectively forming domestic value chains (DVCs), supplied upstream by labor intensive producers. Furthermore, if the DID strategy opens opportunities for Colombian firms to connect to service-oriented GVCs, there can be synergies between the JET reforms in a way that elicits development of linkages to domestic firms for the provision of components. The evidence from the literature on FDI backward linkages for Colombia presented by Kugler (2006) shows how this channel generates employment opportunities for the local labor force, as domestic firms supply intermediate inputs and services to multinational subsidiaries and benefit from FDI technology spillovers.

Therefore, for policy effectiveness, the proposed JET strategy for Colombia in the current context of the COVID-19 crisis requires the capability to boost labor demand by the private sector for workers with diverse sets of skills. This challenge emanates from the fact that two groups of workers have to be targeted: (i) workers from households that were already below the poverty-trap income threshold and (ii) workers from vulnerable households who during the COVID-19 crisis sustained income losses taking them below the moderate poverty line. The dispersed distribution of skills among the workforce is key as a source of potential mismatch. A JET strategy needs a skill formation component to succeed. As stated in the discussion of results, complementary human capital accumulation policies are needed if formal a job access strategy is going to translate into poverty reduction and lower inequality.

The poor and vulnerable may be left out from the formal labor market due to skillbiased modern technologies and increasing robot-intensive production. Then lack of access 
to quality education/training for skill upgrading can leave poor workers locked out from formal jobs in sectors expanded by JET through integration into GVCs and associated expansion through backward linkages of DVCs. In the end, if Colombian firms latching onto GVCs are in capital and/or skill intensive sectors, the short-run effect on poverty and inequality will likely be limited.

In the medium to long run, there can be structural change-inducing opportunities for low-income households to benefit from the formal jobs that could result from expanded GVC linkages. We discuss this possibility and how to extend our CGE analytical framework by allowing for changes in the Social Accounting Matrix (SAM) reflecting new labor market trends, which could yield lower poverty rates and Gini coefficient to be captured in the microsimulations.

In the following section, we present the literature review. In Section 3, we discuss GVC and DID policies in Colombia that articulate the JET agenda. Then, in Section 4, we present our computable general equilibrium (CGE) model, data sources, and microsimulation methodology with the analytical underpinnings of a pilot study to quantify the 10-year impact on poverty and distributional outcomes of JET-oriented reforms targeted to allow better access for Colombian firms to latch onto GVCs as well as to achieve DID. In Section 5, in the COVID-19 context, we present results from microsimulations of potential effects on poverty and employment from GVC- and DID-directed policy reforms. We assess the formal employment benefits for workers in both households above poverty-trap threshold income levels and below, all of whom without higher earnings may remain chronically poor in the future. In Section 6, the findings of the sensitivity analysis are presented, and the robustness of the results from the CGE modeling are discussed. Finally, Section 7 concludes, providing international context for the findings and future research directions.

\section{Literature Review}

In developing countries and emerging markets, there is a potential for GVCs to generate formal job creation. At the same time, complementary measures that lower barriers to international trade and foreign investment can expand the formal sector (World Bank 2020; Shepherd 2013). In Colombia, GVCs can generate productivity and quality gains through specialization (Kugler and Verhoogen 2012), access to imported inputs (Kugler and Verhoogen 2009), and technology spillovers (Kugler 2006). In addition, more generally, GVCs can boost market selection though competition (Criscuolo and Timmis 2017). Another factor to take into account is that a JET formal sector growth strategy, as laid out by the International Development Association (2019), lists as a key cross-cutting area the leveraging of digital technologies. Hence, a key aspect of our analysis is that we incorporate the digital dimension through digital infrastructure development (DID) policies, together with the JET policies that promote GVC integration and lower barriers to international trade and attract FDI.

An important issue for a JET strategy based on the promotion of linkages and integration with global supply chains is that firms connected to GVCs are likely to be capital and skill intensive, limiting the potential of job creation that is suitable for workers in the low-to mid-range of the human capital distribution. This is a limitation of growth policies focused on GVCs, trade openness, and FDI promotion to reduce poverty and inequality. Nonetheless, this effect on factor markets can be mitigated by a boost in labor demand across the board as productivity growth takes off; moreover, the backward linkages generated by the firms connected to GVCs can generate demand for intermediate goods and services from sectors intensive in unskilled labor. At the same time, GVC linkages can yield restructuring in labor markets depending on the factor intensity of different sectors that expand and contract in the reallocation process (Farole 2016). A World Trade Organization (WTO) study by Hollweg (2019) found that when relatively high-tech firms emerge, there can be a rise in the relative demand for skilled workers that increases wage inequality. ${ }^{1}$ In addition, we could envision that with DID policies, the scope for human capital accumulation gets 
amplified through distance learning, as the digital divide closes, and this can make it easier for vulnerable and poor populations to access the formal jobs generated by the JET strategy.

At the same time, the World Bank's World Development Report (2020) provides evidence that expansion by producers in sectors linked to agriculture that integrate with GVCs has been associated with poverty reduction. Evidence by Eaton et al. (2008) has shown how Colombian manufacturers have been able to pioneer explorations into new markets through new destination and new product margins. Case studies by Melendez and Uribe (2012) show that Colombian firms in agro-industrial activities have been able to latch onto GVCs through quality upgrading. For manufacturing, Kugler and Verhoogen (2012) have documented the importance of quality upgrading for industrial development dynamics. Barrientos et al. (2011) analyze workforce composition effects from being connected to the GVCs. ${ }^{2}$ Gyeke-Dako et al. (2017) conducted a study in Ghana and concluded that firms that integrated with GVCs supplied primarily raw materials with relatively low value added but that their workers both had better benefits and wages.

For Colombia, both Echavarría et al. (2019) and Esguerra and Ulloa (2016) suggest that, to boost GVC linkages, tariffs must be lowered and barriers to FDI must be removed. The impact of lower and less heterogenous tariffs on market selection and productivity in Colombia has been documented for the manufacturing sector by Eslava et al. (2004, 2013). This productivity effect can be associated with formal employment, as labor demand increases for expanding establishments, but this will depend on whether factor markets work and are flexible in tandem and whether financial capital is available for firms to upgrade equipment. Haltiwanger et al. (2004) provide general evidence for Latin America on the labor-reallocation impact that enhances productivity of lowering tariff barriers. The evidence for this process in Colombian manufacturing is also documented in another study by Eslava et al. (2010).

The linkage between capital deepening through FDI inflows and employment growth has been explored in theory by Kugler (2009), who also surveys some of the literature on this topic, and it has been explored empirically by Kugler and Rapoport (2007). There are also a number of studies analyzing the regulatory context for FDI in Colombia over time, such as Garavito et al. (2012). Other studies focus on the determinants of the rises in FDI inflows as a share of GDP (Garavito-Acosta et al. 2013; Echavarría and Zodrow 2005) and also how these inflows have impacted Colombian firms (Buitrago and León 2015; Reina et al. 2016).

A third element key for GVC integration, beyond lower barriers to imports and FDI, already highlighted by Departamento Administrativo Nacional de Estadistica (2018) is reduction in logistics costs. As highlighted in a recent by the International Finance Corporation (2020) report, the movement, storage, and flow of goods have been directly affected by the COVID-19 pandemic: "Logistics firms facilitate trade and commerce and help businesses get their products to customers. Supply chain disruptions to the sector caused by the pandemic could, therefore, impact competitiveness, economic growth, and job creation."

Furthermore, an earlier United Nations (2010) study lists challenges to integration with GVCs: (1) absorptive capacity for new technology adoption, (2) liquidity constraints and scarce human capital, (3) ISO certifications and corporate quality control, (4) intellectual property right (IPR) management, (5) difficulties for SME to negotiate with multinational corporations, and (6) diversified entry into GVCs lowers exposure to sectoral external shocks. Another crucial barrier to upgrading the position of local producers in GVCs discussed by Pietrzak et al. (2020) is information asymmetry, as distance from headquarters can be an impediment to know-how transfer and informational flows.

An important factor for GCV-related job creation to benefit workers across the spectrum of the income distribution is occupational mobility. The following taxonomy of skill is proposed by Bechichi et al. (2019): task-based skills, information and communications technology (ICT) skills, administration, communication, sales, and management. Transitions between these broad categories can take from 6 months to 3 years. 
The process for workers with low human capital to transition to jobs requiring skill upgrading can require a substantial investment, with prolonged training periods for sectorspecific technology expertise. In terms of general-purpose skills, Grundke et al. (2017) highlight problem solving and cognitive skills as crucial for workers in GVC firms. ${ }^{3}$ Marcolin and Squicciarini (2018) focus on the role of investments in organizational design and ICT upgrading. Shuzhong et al. (2019) show how GVC integration can boost employment when downstream activity generates substantive labor demand effects. Finally, in terms of future viability in a post-COVID scenario, two issues that loom large are infrastructure adequacy and access to renewable energy sources. The issue of green infrastructure is analyzed by Maestosi et al. (2021), and the challenges of city energy provision facing climate change challenges is tackled by D'Adamo and Rosa (2020).

The research summarized in the literature review covers the frontier of knowledge on GVCs and FDI in relation to their scope to generate poverty and inequality reductions through formal employment creation. The gaps in existing knowledge make clear now more than ever (after the COVID-19 pandemic) the relevance of the jobs and economic transformation (JET) agenda of generating high-quality employment growth in developing countries via formal sector expansion through global value chain (GVC) activity and the attraction of foreign direct investment (FDI) through trade openness.

\section{Reforms in Colombia for JET through GVC Insertion and DID}

There are some recurrent themes in the debate about how to boost formal jobs in Colombia. Two prominent ones are the streamlining of nominal minimum wage growth and the moderation of payroll taxes. On the latter, some progress has been made, but on the former, not much headway has been achieved by the proposal often posed for consideration to introduce differential minimum wages, possibly by location, age, and also sector. Given the complex nature of political economy dynamics for labor market regulatory reform, it makes sense to consider alternate policies that can deliver enhanced formal job creation. ${ }^{4}$ The policy portfolio should encompass both the GVC-oriented approach described below, and for the future of work expansion, ${ }^{5}$ it should also consider strategies and platforms making increasingly flexible the physical location of workers in order to cope remotely with shocks such as the pandemic-both in employment and in their human capital accumulation planning. This can give rise to not only higher prevalence of telework and distance learning but also more automated activity, both in production and education, as robots are immune to pandemics.

First, we provide more details on GVC-related reforms that can foster formal job creation. Then, the sectoral and geographic impact factors of the reforms are highlighted. They are very important for identifying what segment in the labor force and population may benefit from the new formal jobs. Finally, we describe the methodology for assessing how the workers in the wage distribution's lower tail—who will be by and large engaged in informal employment - could potentially transition to the formal sector, not only improving expected income but also better shielding vulnerable households from COVID-19-type shocks through the right mix of private job benefits and public unemployment insurance.

Colombia has experienced very limited insertion into GVCs. The shallow integration of Colombian firms into GVCs has reflected the dominance of primary commodities in the export basket. Incentives have yielded specialization into the mining and oil sectors. In addition to the positive impact on formal job creation dynamics, another benefit of GVC presence in Colombia can be gains in export diversification, which can better buffer the economy in the case of sector-specific external shocks that tend to beset commodities.

The materialization of these benefits requires policy reform in a number of areas, including changes in tariff schedules to reduce dispersion across industries and enhanced regulation in freight and transport markets, as well as rules of engagement that make operations by multinational enterprises more transparent and stable. A major impediment to sufficient fiscal space for transfers to the affected workers and households during the 
COVID-19 crisis has been limited access to foreign exchange, as exports have effectively collapsed with the drop in oil prices.

In this sense, deeper engagement by Colombian producers with GVCs could help mitigate risky acceleration of current account deficits. A further disincentive for GVC participation has been the multiple tariff and nontariff barriers for import entry. Trade policy can become instrumental as a tool for recovery in the aftermath of the COVID-19 pandemic. Figure 1 shows the potential for diverse sectors to spur market integration of producers in the Colombian economy.

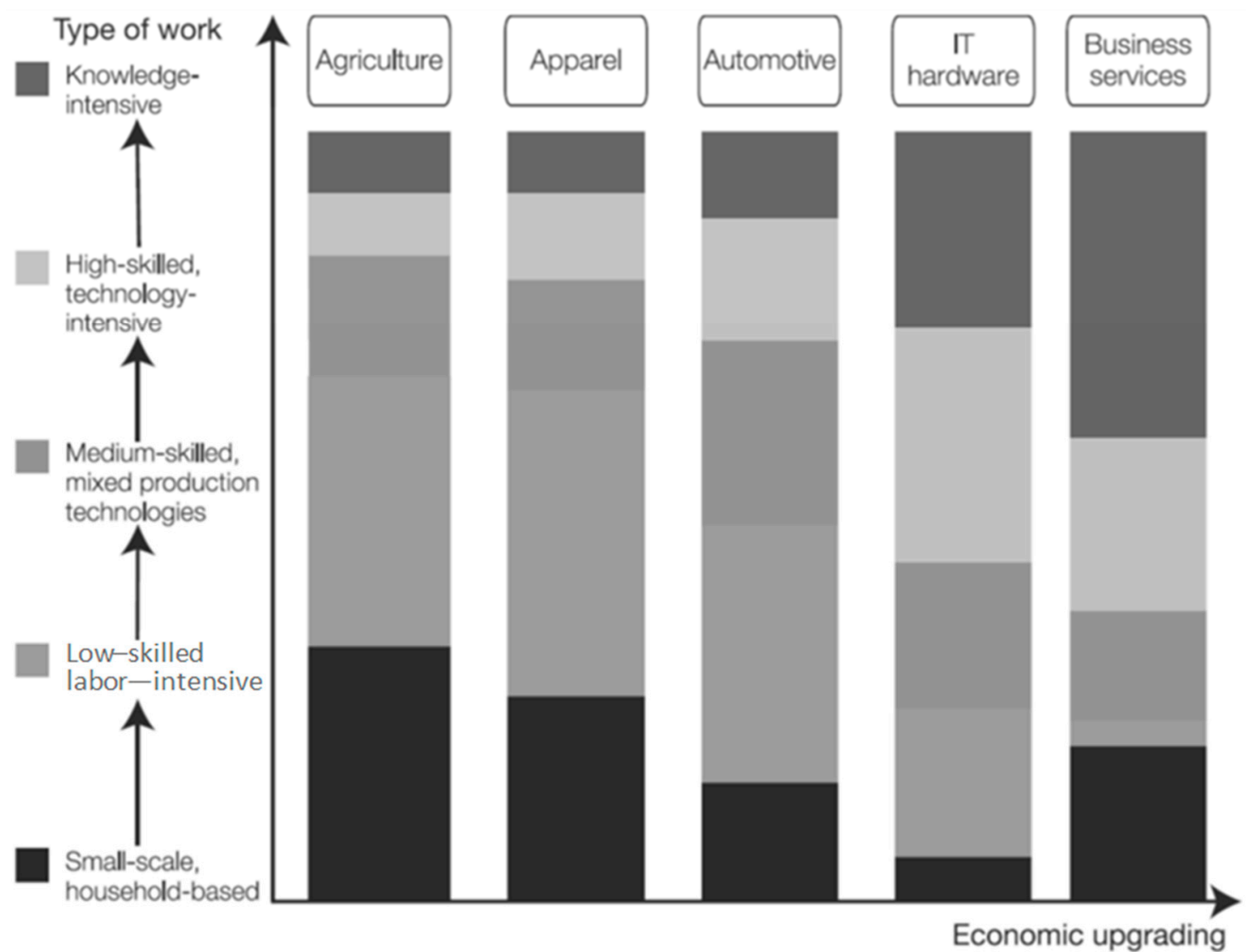

Figure 1. Typology of workforce composition across different sector Global Production Networks. Source: Barrientos et al. (2011).

We focus on three potential general areas for policy reform to promote entry by Colombian enterprises into GVCs:

(a) An important area identified in the Colombia 2019 report by the OECD with potential to ignite private sector dynamics in Colombia is better regulatory frameworks for infrastructure and customs service expansion, as well as lower tariff and nontariff barriers to imports. For example, potential productivity gains can emanate from reforms revamping regulation for enhanced domestic freight transportation and smoother customs procedures to make more efficient the interphase across firms within and between value chains. Additionally, there is need for lower, more homogenous, and stable tariff schedules.

(b) At the same time, greater competition in core sectors, such as logistics and freight transportation, can be instrumental in facilitating Colombia's insertion into global value chains as highlighted in the World Development Report (World Bank 2020) through infrastructure modernization of maritime ports and airports, which could also improve with the removal of barriers to entry for ancillary services provision. In fact, intranational freight costs could drop considerably both with more competition 
and road network modernization in a way that enables Colombian firms to engage with GVCs operating with just-in-time (JIT) inventory strategies to cover international markets. Lower transportation costs from factory to port (and vice versa) are key, as is better transport infrastructure to export and import within GVCs. As highlighted in a recent International Finance Corporation (2020) report, efficient and nimble logistics are a necessary condition for successful GVC insertion.

(c) Further support for entrepreneurship and greater access to finance will also be fundamental for investment into innovative projects to accelerate new firm entry and technology upgrading by existing firms that can supply components to leading edge GVCs. ${ }^{6}$ Foreign direct investment (FDI) has a key role to play through both set up of subsidiaries and technology spillovers. Therefore, the regulation of FDI should be streamlined in a way that stabilizes net inflows. These policies could promote investment as well as exports as drivers of innovation and technological change. At the same time, there is room for reduction in non-tariff impediments for multinationals as well as limits on profit repatriation.

First, in terms of tariff barriers for imports, the mean tariff level across goods and services-at $8 \%$-is not substantially above that observed across the countries that belong to the World Trade Organization (WTO), but the sectoral dispersion and heterogeneity is substantial. For example, Echavarría et al. (2019) estimate that the nominal and effective tariffs on agricultural products are double those in manufacturing. They conclude that not only tariffs but also effective protection rates have a very high standard deviation by international standards. Surprisingly, this dispersion has risen since the early 1990s, when a big push towards trade liberalization was a priority. ${ }^{7}$ Table 1 provides an idea of tariff levels and the scope for reductions in Colombia to achieve greater openness and GVC insertion.

Table 1. Sectoral Tariffs and Imports.

\begin{tabular}{|c|c|c|c|c|c|c|c|c|c|}
\hline Frequency Distribution & Exempt & $0<5$ & $5<10$ & $10<15$ & $15<25$ & $25<50$ & $50<100$ & $>100$ & No VA \% \\
\hline \multicolumn{10}{|c|}{ Agricultural Products } \\
\hline NMF applied (in 2018) & 0.4 & 13.4 & 27.9 & 39 & 0.1 & 0 & 3.4 & 0 & 15.6 \\
\hline Imports (in 2017) & 0.3 & 4.2 & 12.6 & 22.3 & 0.6 & 1 & 3.6 & 0 & 55.3 \\
\hline \multicolumn{10}{|c|}{ Non-Agricultural Products } \\
\hline NMF applied (in 2018) & 59.3 & 9.7 & 9.9 & 15.4 & 0 & 0.4 & 0 & 0 & 5.2 \\
\hline Imports (in 2017) & 49.8 & 17 & 15.7 & 9.4 & 0 & 5.7 & 0 & 0 & 2.5 \\
\hline
\end{tabular}

Source: WTO.

In terms of logistics costs associated with the movement, storage, and flow of goods, lack of efficiency on this front can be damaging for supply chains generally and can cripple any prospects of linkages with GVCs. In Colombia, the indicators are prone to substantial improvement in some areas. The number of transit hours for merchandise in port facilities largely exceeds the average among Latin American countries. Figure 2 shows how the extent of port inefficiency in Colombia far exceeds that in other Latin American countries.

At the same time, the logistics performance index (measured on a 1-5 scale) has improved between 2016 and 2018. This enhancement is due to faster coordination and interface of shipments between transportation modes as well as speedier customs procedures. Colombia's ranking in this category went up to 58 in 2018, from 94 in 2016. Figure 3 shows this evolution. 

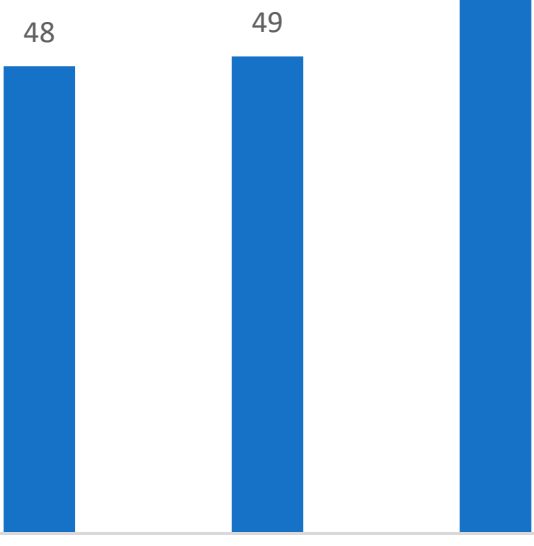

CRI MEX

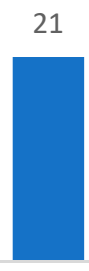

PER

BRA

$\mathrm{CHL}$

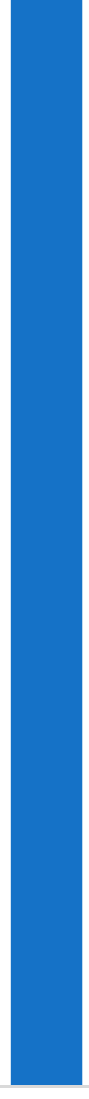

Figure 2. Hours needed to handle exports at port facilities. Source: World Bank, Doing Business 2019.

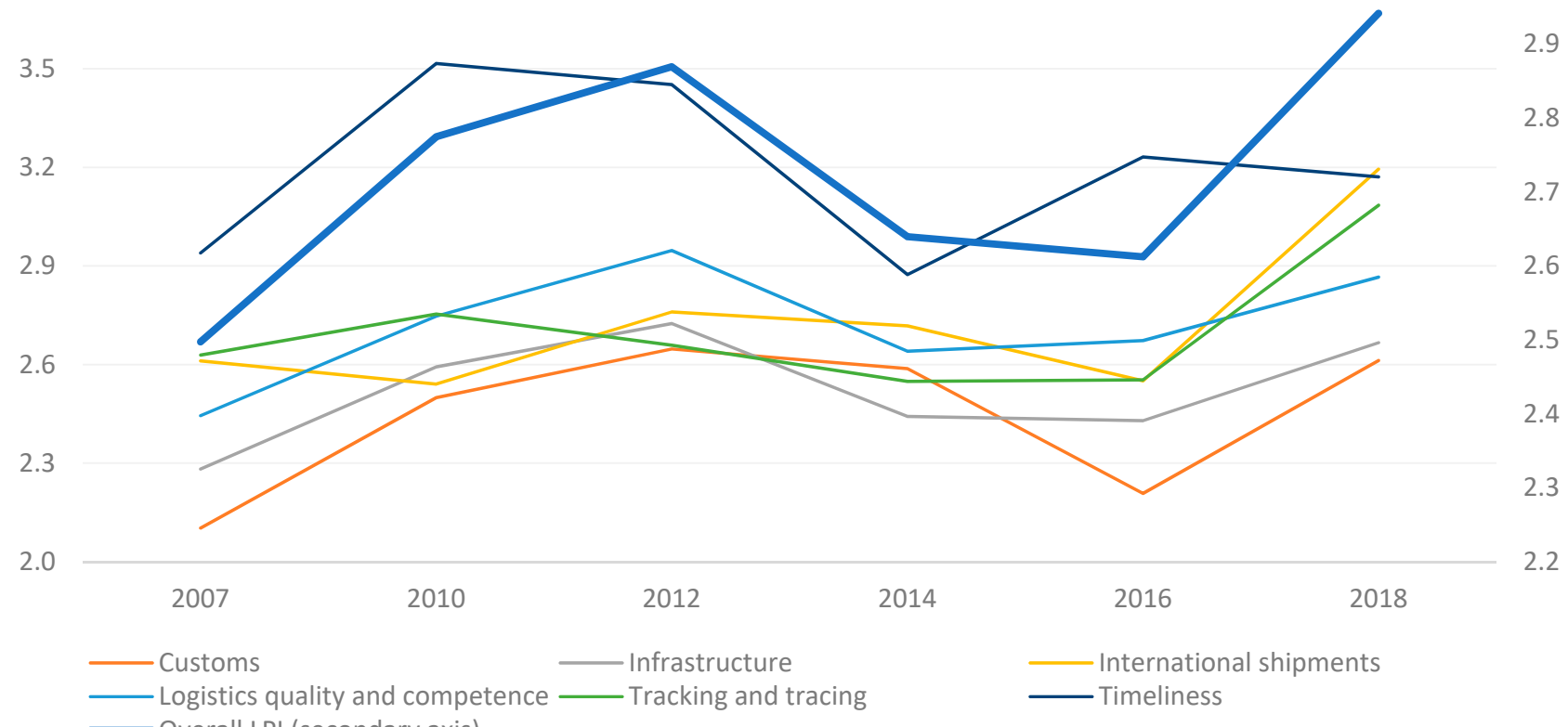

Overall LPI (secondary axis)

Figure 3. Index of logistics performance (from $1=$ Low to $5=$ High). Source: Logistics Performance Index, World Bank. 
In terms of FDI, annual comparisons for Q1 between 2016 and 2020 in Figure 4 show the sectors that absorb the largest share of total FDI inflows:

(i) Electricity, gas, and water (19\% in 2020);

(ii) Oil extraction (16\% in 2020);

(iii) Coal mining (14\% in 2020);

(iv) Agriculture and fisheries ( $2 \%$ in 2020).

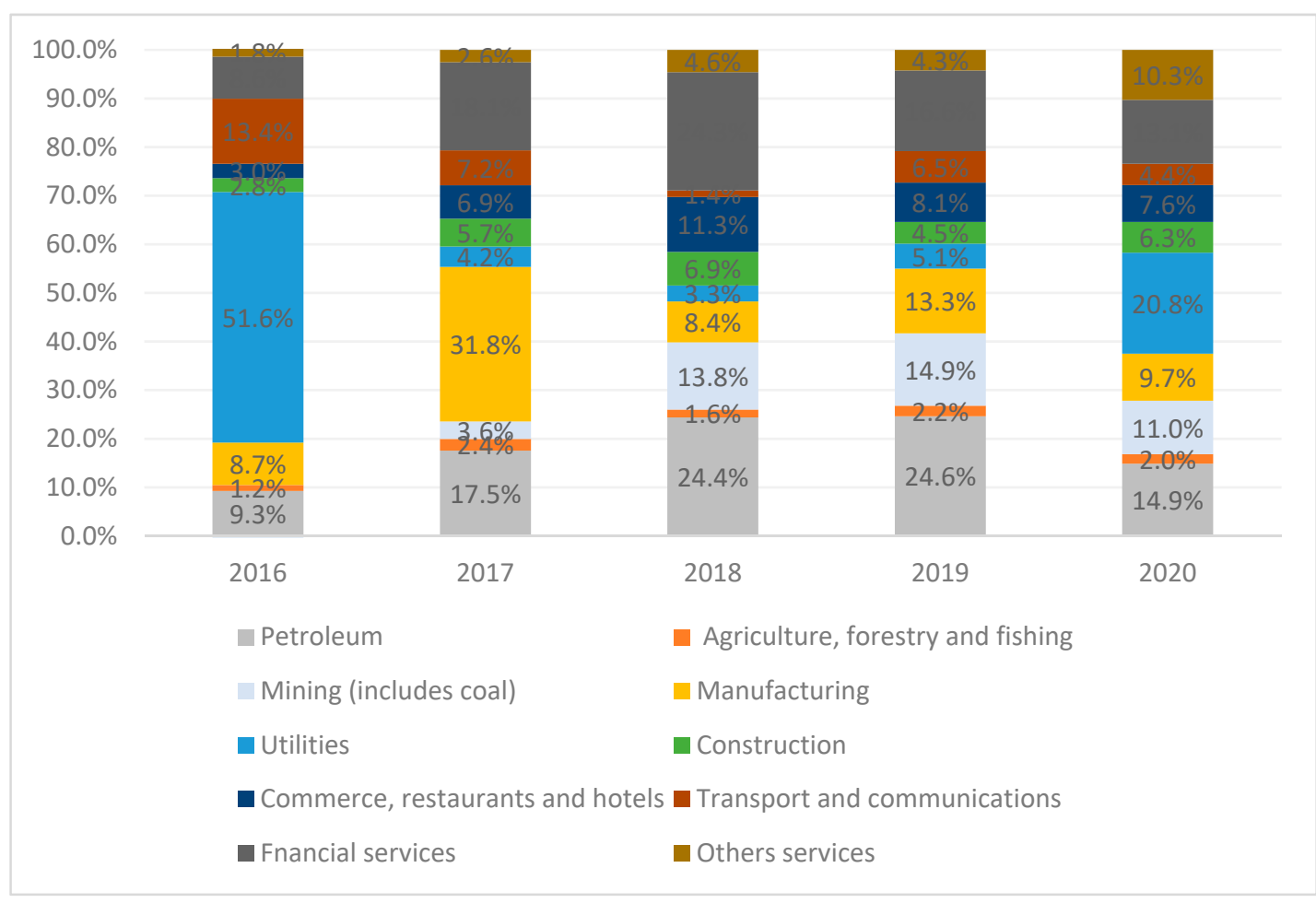

Figure 4. FDI in Q1 (2016-2020). Source: Economics Statistics-MINCIT (https: / / www.mincit.gov.co/estudios-economicos/estadisticas-e-informes/sistemas-de-estadisticas-deconsulta-rapida/estadisticas-economicas-intercambiables-indice). Accessed: 15 December 2021.

Also, related to FDI, Figure 5 shows for the food processing industry for illustration the limited extent of backward and forward linkages associated with multinational corporation activity in Colombia compared to other countries in Latin America. This is especially pronounced in relation to forward linkages. But also salient with regard to backward linkages, which are particularly relevant for technological spillovers (see Kugler 2006), for which Colombia lags in comparison to Mexico, Chile and Costa Rica in the food processing sector.

In terms of the origin of FDI inflows to Colombia, the countries with the highest cumulative share for since 2016 up to Q1 of 2020 are:

(i) U.S. with $18.5 \%$;

(ii) Spain with $16.7 \%$;

(iii) Switzerland with $8.4 \%$;

(iv) Brazil with $7.4 \%$;

(v) England with $7.4 \%$;

(vi) Panama with $7.1 \%$. 
Food Processing

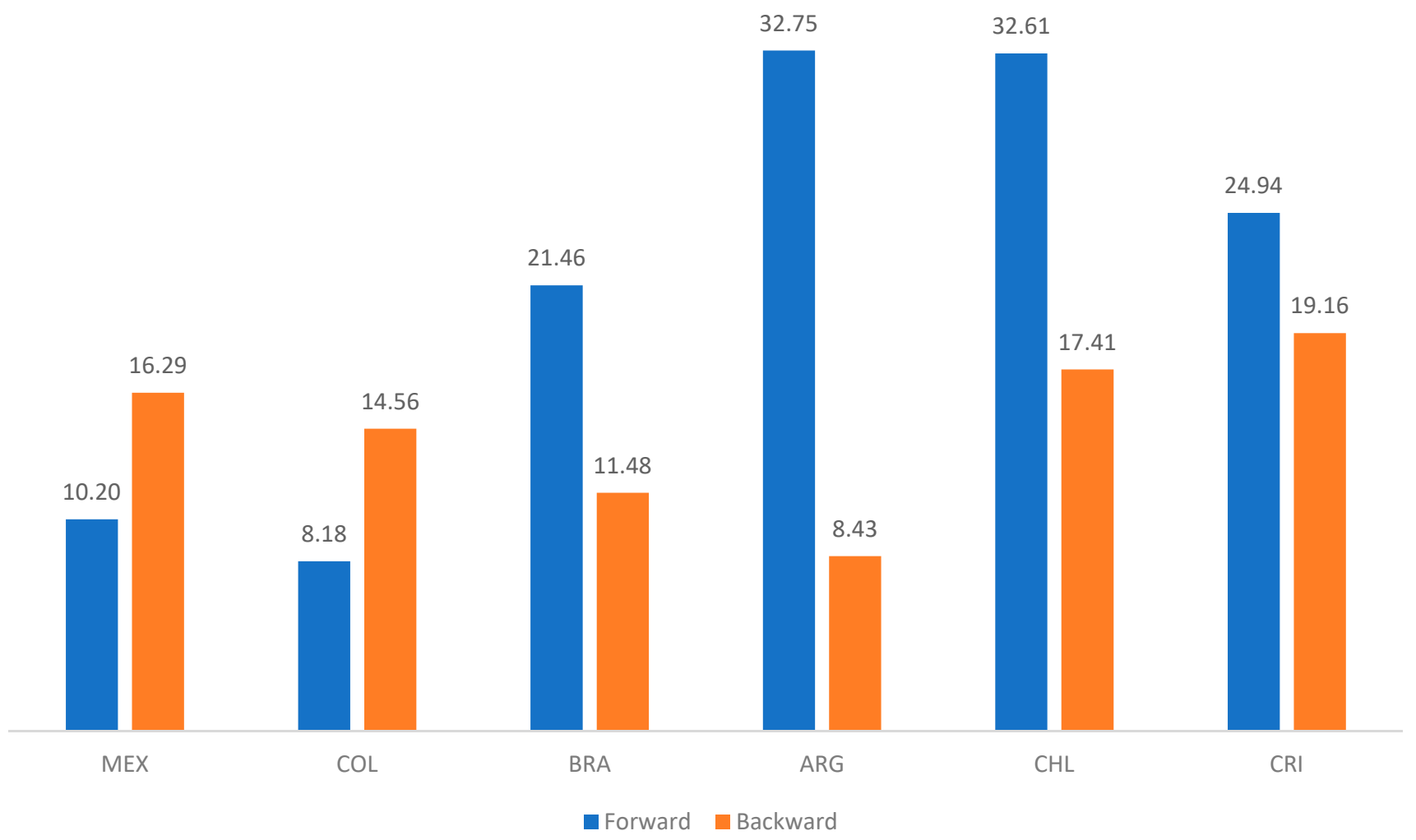

Figure 5. Forward-backward linkage indices for agriculture and the food industry. Source: OECD Economic Surveys: Colombia 2019.

In both the sectoral dimension and the country-of-origin dimension, there is obviously substantially more scope for diversification that would be beneficial for both productivity growth and external shock absorption.

The latest National Development Plan (Plan Nacional de Desarrollo-PND), drafted for the period 2018-2022 by the Government of Colombia's National Planning Department (Departamento Nacional de Planeación-DNP), flagged Colombia's low productivity, high labor market informality, lack of entrepreneurial innovation, and very high taxes, along with distortionary regulations. In this context, the PND aimed to decrease economic concentration in the mining and oil sectors. Explicit policy goals targeted are the promotion of labor market formalization, reduction in transportation and logistical costs, promotion of FDI inflows and GVC linkages, enhancement systems for information sharing between Colombian exporters and potential clients overseas, and also optimization of strategic commercial relations through GVC linkages. The details are in Presidencia de la República de Colombia (2018).

These three sets of reforms have been flagged for their potential to yield gains in terms of formal jobs. This is very important from a macroeconomic perspective. At the same time, it is essential to gauge the potential for these reforms to make a dent in poverty, reduce inequality, and boost shared prosperity. For this to happen, the reforms need to yield higher job creation to further shrink the share of informal employment-which has been stubbornly high in Colombia-around 60\% since the early 1990s. This has meant that many households have had workers with wages very near the poverty-trap income threshold. In the JET strategy context, a key objective of expanding formal sector employment is both to increase earnings, especially for the poor, and reduce income volatility-thereby reducing inequality.

In terms of challenges for the expanded formal work to yield reduction in poverty and inequality, the most likely binding constraint that keeps poor households from benefitting 
from formal job creation through the JET strategy to boost GVC links will be skill mismatch. In particular, the higher labor demand will most likely be concentrated in capital- and skill-intensive sectors. In the short term, this will yield new employment opportunities, most likely for those at the higher end of the human capital distribution. For the rest of the workers, specifically those in poor households, it can take time to access the proper training to match the skill needs of the GVC firms.

We focus on two potential additional areas for policy reform to promote DID by Colombian municipalities:

(a) An important area identified in terms of fiscal space is that while the central government is tightly constrained, many large cities, such as Bogota and Medellin, have ample capacity and fiscal space for indebtedness that would make digital infrastructure investments a very high-yield proposition in terms of direct job creation, telework facilitation, and virtual education expansion.

(b) From the labor supply side, further human capital accumulation is needed. Indeed, vocational training may be an important element of skill upgrading and retooling by youth and other workers. ${ }^{8}$ For example, $96 \%$ of vocational training offerings are in-person. Obviously, under lockdown and social distancing conditions, this poses substantial access problems. The vocational training is primarily supplied by Servicio Nacional de Aprendízaje (SENA). The training courses deal mostly with security services $(12.26 \%)$, commerce and administration $(11.6 \%)$, sales and marketing $(11.21 \%)$, personal services $(10.15 \%)$, and health services $(9.1 \%)$. Table 2 provides a sample of the offerings that could be diversified via virtual and distance learning.

Table 2. SENA Training Programs amenable to Virtual Learning.

\begin{tabular}{|c|c|c|c|}
\hline Name of the Program & Duration & Required Background & Target Qualification \\
\hline International commerce & 12 months & High school & Technician \\
\hline Clothing manufacturer & $880 \mathrm{~h}$ & Primary school & Operator \\
\hline $\begin{array}{l}\text { Logistical support for events and } \\
\text { company services }\end{array}$ & 6 months & Primary school & Aid \\
\hline $\begin{array}{l}\text { Economic management in } \\
\text { international logistics }\end{array}$ & $880 \mathrm{~h}$ & Technician & Specialized technician \\
\hline $\begin{array}{l}\text { Resource management in production } \\
\text { plants }\end{array}$ & 24 months & Junior high school & Technician \\
\hline Integration of logistics & $2208 \mathrm{~h}$ & High school & Technician \\
\hline Agro-industry and food sector & 12 months & Junior high school & Technician \\
\hline Sugar agro-industry & $2200 \mathrm{~h}$ & High school & Technician \\
\hline Aquaculture & 24 months & Junior high school & Technician \\
\hline Precision agriculture & 24 months & Junior high school & Technician \\
\hline Agrobiotechnology & 24 months & Junior high school & Technician \\
\hline Freight preparation & $1296 \mathrm{~h}$ & Primary school & Aid \\
\hline $\begin{array}{l}\text { Preparation of labs for analysis and } \\
\text { tests for industry }\end{array}$ & $2208 \mathrm{~h}$ & Primary school & Technician \\
\hline $\begin{array}{l}\text { Preparation and operation of } \\
\text { machinery for industrial production }\end{array}$ & 12 months & Primary school & Technician \\
\hline $\begin{array}{l}\text { Storage and packaging of } \\
\text { merchandise }\end{array}$ & $880 \mathrm{~h}$ & Primary school & Aid \\
\hline $\begin{array}{l}\text { Analysis and development } \\
\text { information systems }\end{array}$ & 24 months & Junior high school & Technician \\
\hline $\begin{array}{c}\text { Commercial management and } \\
\text { telemarketing }\end{array}$ & $1760 \mathrm{~h}$ & High school & Technician \\
\hline Call center operation & $2208 \mathrm{~h}$ & High school & Technician \\
\hline Analysis of chemical samples & 12 months & High school & Technician \\
\hline Aircraft support in airports & $1296 \mathrm{~h}$ & Primary school & Operator \\
\hline
\end{tabular}


This portfolio of policies completes the JET and DID strategies considered as potential reforms for mitigating the rise in poverty and inequality as a result of the pandemic in Colombia. Other aspects of reform not considered here include the institutional design aspect of the separation of powers, see for example Kugler and Rosenthal (2005), and issues related to regulatory dimensions of corruption and law enforcement, see for example Kugler et al. (2005).

\section{Methodology and Data}

The set of three types of reforms for GVCs and laid out as part of JET implementation in Colombia, as well as the two DID policies detailed in the previous section, were used to quantify projected effects not only on formal jobs but also poverty and wage distribution changes. To do this we relied upon existing analytical tools and available data-such as the CGE model developed by Departamento Nacional de Planeación's Division de Estudios Económicos (Colombian Planning Department's Economic Studies Division) with a linked calibrated SAM. To model the open-economy dimensions-including exports, imports and capital flows (encompassing FDI) — we built modules based on the global trade analysis program (GTAP).

\subsection{Data Sources}

To model disaggregated heterogenous labor market outcomes, we conducted microsimulations to capture wage distribution dynamics to assess changes in poverty and inequality based as benchmark on the household survey for 2018 (Gran Encuesta Integrada de Hogares-GEIH).

\subsubsection{Social Accounting Matrix-SAM}

The construction of an important input for our work, i.e., the Social Accounting Matrix (SAM), has been in the past a collaborative effort between Colombia's Planning Department and the World Bank. The SAM that can be used in the simulation to ascertain who will access the jobs created by JET reforms is a matrix that records all transactions among all actors (i.e., households, firms, government) in different markets in the economy.

The SAM includes 25 sectors of production, and there are eight worker categories by age, level of schooling, and work status (formal or informal). The public sector is partitioned between national government and social security. With the rest of the world, there are interactions through exports and imports of goods and services as well as capital flows in and out. The information in the SAM for the analysis in this paper was generated by the Colombian Planning Department's Economic Studies Division using a general equilibrium base for 2014 built from national accounts and complemented by a set of estimated elasticities for supply and demand, in multiple markets, that feed into the dynamics of the model through its recursive structure.

\subsubsection{Household Survey (Gran Encuesta Integrada de Hogares-GEIH)}

For the microsimulations, the information about individuals in the workforce in Colombia was obtained from the Gran Encuesta Integrada de Hogares (GEIH), produced by Departamento Administrativo Nacional de Estadística (DANE). DANE has been collecting cross-sectional data on labor force participation, earnings, and quality of life indicators of households since the 1960s.

However, since the start of this data collection process and up to 2006, data were only available for 13 cities and their metropolitan areas. Starting in 2006, the entire survey covers 24 cities and their metropolitan areas. In addition, the modules on labor markets and household earnings also cover rural sectors.

The purpose of this data collection effort is to provide information about the size and structure of the labor force (employed, unemployed, and inactive) as well as about the socio-demographic characteristics of the population. GEIH is a nationally representative survey that collects exhaustive socioeconomic information, including observable worker 
characteristics, determining labor market outcomes such as gender, age, occupation, and schooling achievement. In addition, the survey has questions about job characteristics such as sector, wage, and social security contributions.

\subsection{Macroeconomic Linkages: CGE Model Simulations}

CGEs capture the linkages within sectors in the economy to analyze and quantify interactions across markets (labor, capital, goods and services, international linkages, etc.) and sectors (supply chain connections) in the face of external shocks. The CGE used for our simulations was the main tool developed by the Colombian Planning Department's Economic Studies Division (DNP-DEE) for this kind of exercise (Macepes). This model has been used in recent analyses of intersectoral linkages (Hernández-Diaz et al. 2019a, 2019b).

The structure of the labor market in the model is detailed in Bussolo et al. (2011). The dynamics between the formal and informal sector allow for flows between labor market segments that are responsive to wage premia and probability of detection in payroll tax or minimum wage avoidance.

This model is amenable to simulate the impact of a broad range of external shocks and policy changes, and was most apt for the current analysis as it emphasizes labor market dynamics job creation and destruction rates and wage rate changes, with estimated outcomes that permit analyses of poverty rates and income distribution through microsimulations. The building blocks for the CGE are:

(1) Economic agents in the model include households, firms, government, and the rest of the world.

(2) Consumption is derived from optimal choices by utility-maximizing households.

(3) The production technology is CES (constant elasticity of substitution), and it yields optimal output and factor demands (including capital, skilled workers, and unskilled workers) for profit-maximizing firms that are price takers in both input and output markets.

(4) The model is based on the Social Accounting Matrix (SAM), described in detail in the next section. Generally, there are 25 sectors of production, there are eight worker categories by age, level of schooling and work status (formal or informal). ${ }^{9}$

(5) The public sector is partitioned between national government and social security.

(6) The labor market dynamics with flows between the formal and informal sector are driven by a Harris-Todaro type of arbitrage equation. The flows will depend on the formal-informal wage gap and the unemployment rate-which determines the expected wage in the formal sector. ${ }^{10}$

(7) The open-economy dimension is based on a global dynamic CGE framework with a multi-regional market structure generated by a module from the global trade analysis project (GTAP).

(8) Within periods, wages are fixed but are updated over the period. As in Calvo (1983), this modeling of wage dynamics generates wage updates between periods.

(9) For each labor market segment (formal or informal), the adjustment can be through quantities or prices, depending on how far the actual unemployment rate is from the natural rate (or the non-accelerating inflation rate of unemployment).

(10) As the SAM only permits inter-group wage gap calculations, the distributional aspects in the model are captured through our own microsimulations, detailed in the next sub-section.

We used the CGE model to project changes under different COVID-19 scenarios in sectoral employment shares and aggregate demand. In 2020, the actual strategy to flatten the curve that was initially implemented from 24 March until 13 April, then the quarantine was extended by 14 days-from 27 April to 11 May initially, after which a further 14 days were added until 25 May, and then at that point an extension was made until 1 July. A plan to gradually ease restrictions for key sectors in terms of on-site employment, such as construction and agriculture, was implemented. In addition to the sectors supplying essential services, manufacturing was added, as well as other retail and hospitality outlets. 
The use of face masks and other social distancing restrictions were compulsory and not subject to personal choice. These measures aimed to balance mitigation of health risks with creation of opportunities to generate income by the workforce-especially poor households, whose informal workers were mostly unable to telework. The stated objective was to save both lives and livelihoods.

Given that the CGE was calibrated with the SAM to generate labor market aggregate outcomes, such as employment and wages, we characterized the mean income per worker group for microsimulations to estimate distributional outcomes such as poverty rates and the Gini coefficient. In order to examine these distributional impacts, we relied on successive iterations of non-parametric random perturbations and the labor market outcomes by type of worker, sector, and location simulated with the CGE, which then were applied to the working age population (Vos et al. 2006). We applied variations on the unemployment rate, wages, and the sectoral composition of employment. We considered changes in unemployment and wages, as well as sectoral employment for different age groups and local labor markets, to construct poverty incidence and inequality indicators. The model had three margins of macroeconomic balance: the investment-savings balance, the fiscal balance (public savings), and the current account balance (foreign savings). Private savings were given by disposable income and the marginal propensity to save. Tax revenues were endogenous since both government spending and the fiscal deficit were exogenous. The exchange rate was endogenous and the current account balance was exogenous.

The growth scenarios underlying the CGE simulations for 2020-2021 also included the impacts of potential described JET reforms and are detailed in Table 3. Initially, we built as our benchmark scenario one that incorporated the economic effects of COVID-19-on the basis of scenarios developed by Lamprea et al. (2020).

Table 3. Growth Scenarios for the Colombian Economy: 2020-2021.

\begin{tabular}{|c|c|}
\hline Scenario & Description \\
\hline COVID-19 & $\begin{array}{l}\text { Scenario of limited growth due to lockdowns } \\
\text { and the global recession due to the pandemic }\end{array}$ \\
\hline Recovery Scenario & Scenario of DNP's expected growth for 2021 \\
\hline $\begin{array}{c}\text { Recovery Scenario with Policy Reforms to } \\
\text { Decrease Logistics Costs }\end{array}$ & $\begin{array}{c}\text { Scenario in } 2021 \text { if there are policy reforms } \\
\text { conducive }\end{array}$ \\
\hline Recovery with Tariff Reduction Scenarios & $\begin{array}{l}\text { Scenarios with different levels of tariff } \\
\text { reductions at } 53 \% \text { and } 100 \%\end{array}$ \\
\hline Recovery Scenario with a $10 \%$ Rise in FDI & $\begin{array}{c}\text { Recovery scenario with removal of barriers to } \\
\text { FDI, generating higher inflows }\end{array}$ \\
\hline
\end{tabular}

Then, we estimated what a potential 2021 rebound scenario might look like. On the basis of that scenario, we simulated the effect of three policies for boosting GVC linkages that were envisioned by the government. First, we considered policies to reduce logistics costs, as prescribed by the government in 2018 (about 3\%). ${ }^{11}$ Second, we modeled a reduction in tariffs by $50 \%$ or $100 \%$. Third, we simulated a $10 \%$ rise in FDI inflows as barriers were lowered. Finally, we measured the combined effect of the three policies lowering logistics costs, tariff levels, and dispersion, and finally barriers to FDI. The simulations are summarized in Table 4. 
Table 4. Simulated effects of COVID-19 on aggregate indicators and labor markets.

\begin{tabular}{|c|c|c|c|c|c|c|}
\hline & $\begin{array}{c}\text { COVID-19 } \\
\text { (1) }\end{array}$ & $\begin{array}{c}\text { Economic } \\
\text { Recovery (2021) } \\
(2)\end{array}$ & $\begin{array}{c}\text { Lower Logistic } \\
\text { Costs (2021) } \\
\text { (3) }\end{array}$ & $\begin{array}{l}\text { Unilateral Cut of } \\
\text { Tariffs (2021) } \\
\text { (4) }\end{array}$ & $\begin{array}{l}\text { FDI Growth } 10 \% \\
(2021) \\
(5)\end{array}$ & $\begin{array}{c}(3)+(4)+ \\
(5)\end{array}$ \\
\hline \multicolumn{7}{|l|}{ Macroeconomic indicators } \\
\hline GDP $(\%)$ & -6.6 & 3.0 & 3.4 & 3.3 & 3.9 & 5.1 \\
\hline Consumption (\%) & -7.6 & 8.0 & 8.5 & 8.3 & 9.0 & 10.5 \\
\hline Investment $(\%)$ & -10.0 & -9.9 & -9.0 & -10.0 & -5.3 & -3.8 \\
\hline Investment ( $\%$ of GDP) & 21.9 & 19.2 & 19.3 & 19.1 & 20.0 & 20.1 \\
\hline Exports (\%) & -6.9 & 1.8 & 2.6 & 2.7 & 1.6 & 4.5 \\
\hline Imports (\%) & -3.8 & 2.4 & 3.6 & 2.8 & 5.9 & 8.6 \\
\hline Exchange real (\%) & 107.9 & 106.7 & 105.9 & 108.1 & 110.1 & 106.9 \\
\hline \multicolumn{7}{|l|}{ Fiscal indicators } \\
\hline Collection tax (\% of GDP) & 23.6 & 19.8 & 19.8 & 19.6 & 19.9 & 19.3 \\
\hline Public savings ( $\%$ of GDP) & -0.6 & -4.4 & -4.3 & -4.5 & -4.1 & -4.2 \\
\hline \multicolumn{7}{|l|}{ Labor market } \\
\hline \multicolumn{7}{|l|}{ Unemployment rate $(\%)$} \\
\hline Total & 12.58 & 10.97 & 10.90 & 10.94 & 10.87 & 10.70 \\
\hline Young/unskilled formal & 21.17 & 18.79 & 18,68 & 18.74 & 18.64 & 18.40 \\
\hline Young/skilled formal & 26.78 & 23.67 & 23.54 & 23.60 & 23.51 & 23.22 \\
\hline Adult/unskilled formal & 9.44 & 8.26 & 8.19 & 8.23 & 8.16 & 8.02 \\
\hline Adult/skilled formal & 12.95 & 11.05 & 10.98 & 11.02 & 10.97 & 10.80 \\
\hline \multicolumn{7}{|l|}{ Job creation (thousands of people) } \\
\hline Total & -497.5 & 629.8 & 648.8 & 638.9 & 656.3 & 698.6 \\
\hline Formal & -404.1 & 574.3 & 593.2 & 583.3 & 600.8 & 642.8 \\
\hline Informal & -93.4 & 55.4 & 55.6 & 55.5 & 55.5 & 55.8 \\
\hline Informality rate & 58.8 & 57.4 & 57.3 & 57.3 & 57.3 & 57.2 \\
\hline
\end{tabular}

Source: DNP data and authors' calculations.

\subsection{Granular Labor Market Effects: Partial Equilibrium Microsimulations}

For the microsimulation part of the analysis, we developed a static microsimulation model to predict poverty and inequality in scenarios with and without COVID-19. We followed the partial equilibrium analysis developed by van de Walle and Nead (1995), which captured the short-run effects of policies before any potential behavioral response.

We did not consider second-round effects accruing from social and economic reactivation programs in order to focus on the poverty and distributional impacts of COVID-19, the recovery, and the GVC-related policies. Our microsimulations modeled five scenarios. We first started from a counterfactual of no COVID-19, where there was no pandemic impacting earnings and employment. We call this benchmark scenario "Counterfactual, no COVID-19.".

Second, we used microdata to identify which workers were affected by the lockdown (starting on 24 March 2020), following a sequential four-step procedure, described in the next paragraph. Once we identified workers affected by COVID-19, we estimated that their pre-lockdown income would be substantively reduced by 50 percent during the period of the lockdown, which we assumed to be three months-that is, April, May, and June. ${ }^{12}$ This captured an average of different possible earning losses, including pay cuts, furloughs, and possible informal or side activities during lockdown (call center work, manufacturing/sale of face masks, for example).

The initial identification of workers in affected sectors of the economy was as follows. In the first step we identified the economic sectors necessary to fight the virus: utilities, public administration and defense, human health and social work, and extraterritorial organizations (such as embassies). In the second step, we defined all workers in essential services as unaffected by the pandemic. In Colombia, these services are defined by the Government, consisting of 158 sectors outlined in Decree 457. Sectors we categorized as essential included those related to food production and distribution, the sale of medicines, the production and distribution of gasoline, and news agencies. In the third step, we looked at the job performed by the worker. If the task could safely be done from home or elsewhere, the worker was categorized as occupationally unaffected. In Colombia, we identified 29 tasks out of a total of 83 that were amenable to telework and that were 
compatible with lockdown employment, including teachers and white-collar professionals. Finally, the fourth step determined exposure to the pandemic because of workplace: if the person worked on the street, any open space, or in a factory with more than 50 people, even in a non-affected sector, she was classified as affected (Figure 6).

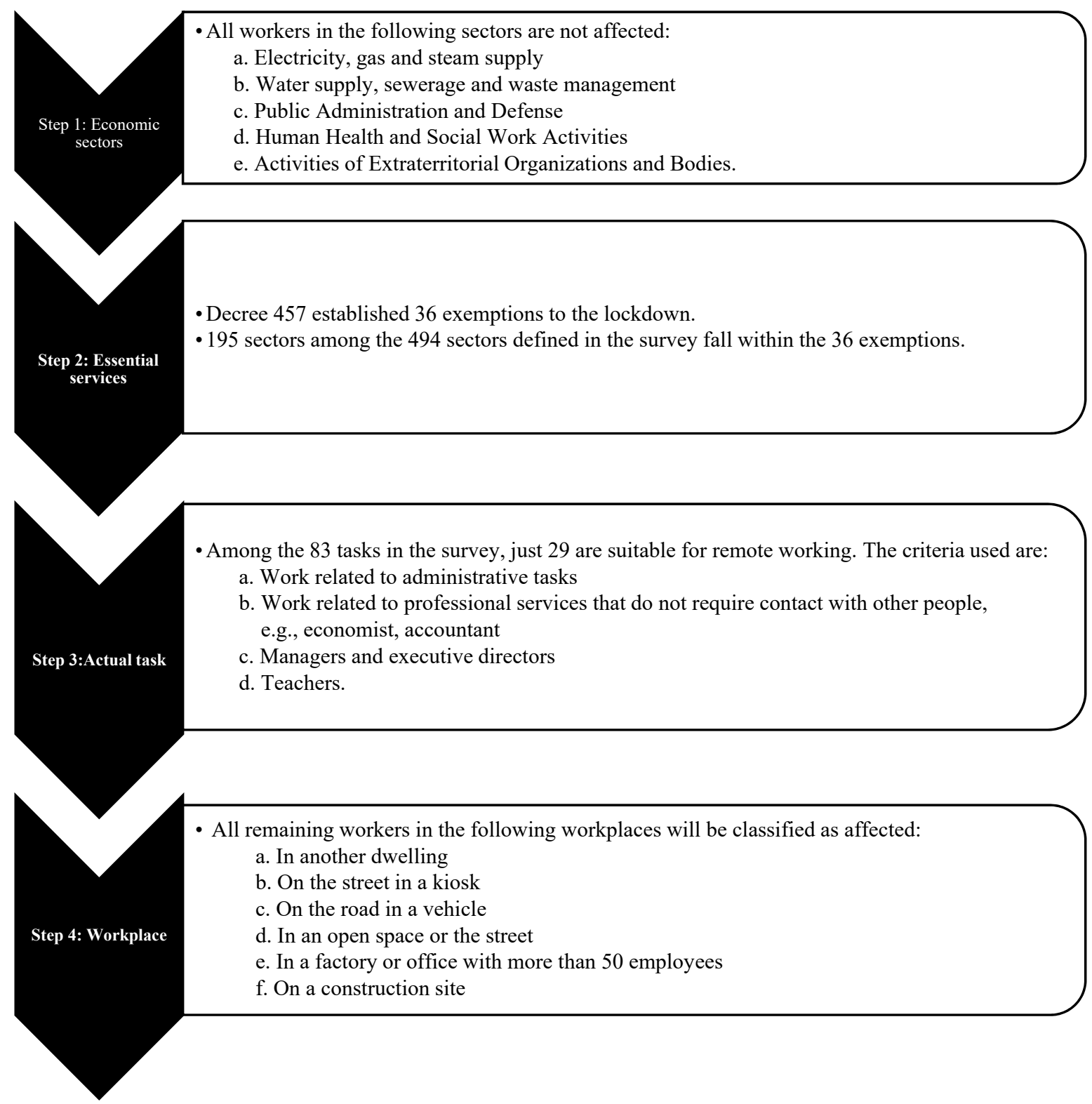

Figure 6. Steps to identify affected workers and their application to Colombia. Source: Authors calculations using Gran Encuesta Integrada de Hogares 2018 (Colombian Hosuehold Survey).

Third, we used the results from the CGE macrosimulations to determine the employment status and income levels of both affected and unaffected workers at the end of the year 2020. The pandemic was assumed to last through the entirety of 2020, so after the three months of the lockdown and the progressive reopening of the economy, workers would start recovering their jobs. At this point we used the predictions from the macroanalysis using the CGE to determine the distribution of unemployment by sector and type of workers (defined by their age, qualification, and formal status). We randomized the workers in each sector and type that each month remained unemployed or exited unemployment to ensure that the numbers by end of 2020 were consistent with the CGE-generated simulations. These two steps, third and fourth, allowed us to determine the immediate impact of the 
lockdown (for three months) and the subsequent effects of the pandemic through 2020 (end of December 2020). We call this scenario "COVID-19, 2020.

Fourth, we modeled the new changes in employment and earning in 2021 using the CGE macrosimulations results. This part of the analysis allowed us to estimate the effects of the baseline economic recovery foreseen in 2021. This is the "COVID-19, 2021 no reforms" scenario. Fifth, and finally, we estimated the effects specific to improvements in logistics, tariff slashing, and increases in foreign direct investments. We call these scenarios, "COVID19, 2021 logistics," "COVID-19, 2021 tariffs," and "COVID-19, 2021 FDI," respectively. We also report a scenario where all reforms are considered simultaneously: "COVID-19, 2021 GVC integration."

In each of these steps, we generated a new distribution of final household income across households based on the impacts (or lack thereof) of the lockdown, lingering pandemic, recovery (in 2021), and reforms (in 2021). This distribution was compared with income distribution in the non-pandemic counterfactual. Specifically, our baseline disposable income distribution in the counterfactual was defined as:

$$
\Phi(\mathrm{Y})_{0}=\Sigma_{\mathrm{h}} \theta_{\mathrm{h}} \Sigma_{\mathrm{i}, \mathrm{j}}(\mathrm{L}+\mathrm{P}+\mathrm{N}+\mathrm{S}+\mathrm{H})_{\mathrm{i}, \mathrm{j}}
$$

where $\Phi(Y)_{0}$ describes the baseline distribution of incomes across Colombian households without the pandemic. The income of household $h$ is the sum of all income sources that each $\mathrm{j}$ member provides to the household-labor, L; pension income, $\mathrm{P}$; and non-labor market incomes, $\mathrm{N}$; and social transfers whether received, in cash or in kind, S; finally, we include $\mathrm{H}$, the rent imputation for those households that own their dwelling. Importantly, S, social transfers, during the counterfactual of no-COVID-19, do not include any transfer that is expanded or created to mitigate COVID-19. ${ }^{13}$

When the lockdown was declared, the pandemic continued to affect employment through 2020, and recovery and reforms took place in 2021, all affected workers saw their labor income reducing through 2020 and increasing through 2021. The microsimulation exercise considered the four sequential criteria described in Figure 1 to determine whether an individual's labor condition was impacted.

Based on that classification, we generated simulated distributions of disposable incomes where the labor income for occupationally affected workers was reduced (to the baseline 50 percent or any other proportion one might want to simulate, $\mathrm{L}^{\prime}$ ), without the social transfers and/or economic recovery benefits increase as the result of mitigation interventions. In other words, in simulated scenarios with COVID-19, S' included all social transfers whose coverage or benefits already existed prior to COVID-19,

$$
\Phi(\mathrm{Y})_{\mathrm{sim}}=\Sigma_{\mathrm{h}} \theta_{\mathrm{h}} \Sigma_{\mathrm{i}, \mathrm{j}}\left(\mathrm{L}^{\prime}+\mathrm{P}+\mathrm{N}+\mathrm{S}^{\prime}+\mathrm{H}\right)_{\mathrm{i}, \mathrm{j}}
$$

We used the Gran Encuesta Integrada de Hogares (GEIH) produced by the national statistical office, the Departamento Administrativo Nacional Estadístico (DANE). This detailed household income survey is collected monthly and the latest available with corrected incomes was the 2018 wave. This contained 231,128 households, a sample that was representative nationally, on an urban-rural basis, and for 24 departments and 13 capital cities (Departamento Administrativo Nacional de Estadistica 2018). These were the official data used to compute poverty and labor market indicators such as unemployment rates.

\section{Main Results and Discussion}

Here, we report the impacts of COVID-19 and the recovery pattern associated with GVC and DID reforms on poverty and inequality post-pandemic. The impact of COVID-19 ranged between increases of 8.1 to 16.0 percentage points (pp) in headcount total poverty rates (FGT0), and 3.1 to $7.8 \mathrm{pp}$ for extreme poverty. This means that between 3.9 to 7.7 million additional people became poor as a result of COVID-19, which would add to the 13.1 million already poor individuals in Colombia (in the absence of the COVID pandemic). ${ }^{14}$ The low-bound impact reports the results for the baseline "COVID-19, 2020" 
scenario of a three-month lockdown, yielding a 50 percent drop in labor incomes among impacted workers and no additional mitigation policies. Allowing for a larger income loss, for example 100 percent of pre-COVID-19 labor incomes would double the impacts on the extreme and total poverty headcounts (See Table 5). The contribution of these results is to highlight the devastating effect on poverty of COVID-19 in Colombia through labor market impacts.

Table 5. Simulated effects of COVID-19, recovery, and reforms on poverty and inequality.

\begin{tabular}{|c|c|c|c|c|c|c|c|c|}
\hline & \multirow{2}{*}{$\begin{array}{l}\text { Counterfactual, } \\
\text { no-COVID }\end{array}$} & \multicolumn{2}{|c|}{ COVID-19, 2020} & \multicolumn{5}{|c|}{ COVID-19, 2021} \\
\hline & & $\begin{array}{c}\text { Baseline: } \\
\text { 50\% Income } \\
\text { Loss }\end{array}$ & $\begin{array}{l}\text { Robustness } \\
\text { Check: } 100 \% \\
\text { Income Loss }\end{array}$ & No Reform & Logistics & Tariffs & FDI & All Reforms \\
\hline $\begin{array}{c}\text { FGT0, extreme } \\
\text { poverty } \\
\text { headcount }\end{array}$ & 7.2 & 10.3 & 15.0 & 8.1 & 8.1 & 8.1 & 8.0 & 7.9 \\
\hline $\begin{array}{l}\text { Number of } \\
\text { extreme poor }\end{array}$ & $3,508,285$ & $4,993,760$ & $7,279,577$ & $3,924,250$ & $3,894,984$ & $3,919,809$ & $3,861,277$ & $3,823,283$ \\
\hline $\begin{array}{l}\text { FGT0, total } \\
\text { poverty } \\
\text { headcount }\end{array}$ & 27.0 & 35.1 & 43.0 & 27.3 & 27.2 & 27.3 & 27.2 & 27.0 \\
\hline $\begin{array}{l}\text { Number of } \\
\text { total poor }\end{array}$ & $13,072,592$ & $16,967,107$ & $20,817,440$ & $13,212,302$ & $13,179,007$ & $13,203,422$ & $13,147,904$ & $13,084,038$ \\
\hline $\begin{array}{l}\text { FGT1, extreme } \\
\text { poverty gap }\end{array}$ & 2.7 & 3.7 & 5.3 & 3.4 & 3.4 & 3.4 & 3.4 & 3.3 \\
\hline $\begin{array}{l}\text { FGT1, total } \\
\text { poverty gap }\end{array}$ & 9.8 & 13.5 & 17.9 & 10.5 & 10.4 & 10.4 & 10.4 & 10.3 \\
\hline $\begin{array}{l}\text { Inequality, } \\
\text { Gini coefficient }\end{array}$ & 51.7 & 52.8 & 54.5 & 51.9 & 51.8 & 51.9 & 51.8 & 51.7 \\
\hline
\end{tabular}

Source: GEIH and authors' calculations.

The poverty gap (FGT1) or the average gap to the poverty line, goes up in 2020 as a result of the pandemic. It increases by a third with respect to the counterfactual scenario when the income shock is assumed to be 50 percent of the pre-COVID earnings among workers in affected sectors. The poverty gap doubles when the income shock is assumed to be 100 percent (Table 5, rows FGT1). Finally, inequality rises, a relatively modest increase of $1.1 \mathrm{pp}$ in the Gini index (with respect to 51.7 in the counterfactual of non-COVID). This is most likely a reflection of the wide scope of the crisis, which has been reported to affect not only poor and vulnerable classes but also middle- and upper-income classes (Cuesta and Pico 2020). The contribution of these results is to highlight the overarching nature of the effect of the labor market impacts of COVID-19 across the income distribution in Colombia.

All the substantial increases in poverty and the more moderated effects on inequality are almost fully reversed in 2021 as a result of the recovery. Total poverty in 2021 at 27.3 percent is only 0.3 pp higher than in the 2020 counterfactual. Extreme poverty in 2021 at 8.1 percent is about $0.9 \mathrm{pp}$ higher than in the counterfactual. Additionally, the Gini index in 2021 is just 0.2 pp higher than in the counterfactual.

More importantly, the additional reforms related to cuts in logistic costs, full reduction in tariffs, and a 10 percent increase in FDI do not translate in any significant additional reduction in poverty or inequality. This is a result of the limited increase in direct employment opportunities (or earnings) that the reforms considered would bring compared with the no-reform economic recovery scenario considered to disadvantaged populations, and the fact that indirect opportunities through backward linkages need to be incorporated. The contribution of these results is to highlight the resilience of Colombian labor markets and the limited short-term impact on formal employment of outward-oriented policies. The cumulative impact on formal employment substantial general labor market dynamics over the span of a decade in terms of formal job generation but the impact in terms of 
poverty and inequality reduction turns out to be limited. The reasons for this might be related to the distribution of skills and human capital precluding the access of the poor and vulnerable benefiting from the new jobs generated by the JET and DID reforms. Table 6 shows the actual GDP growth projections linked to the JET reforms.

Table 6. GDP growth projections from CGE simulation with Global Value Chain (GVC) reforms.

\begin{tabular}{cccccc}
\hline & BAU & $\begin{array}{c}\text { Unilateral Cut of } \\
\text { Tariffs (1) }\end{array}$ & $\begin{array}{c}\text { Lower Logistics } \\
\text { Costs (2) }\end{array}$ & $\begin{array}{c}\text { FDI Growth } \\
\text { 10\% (3) }\end{array}$ & (1) + (2) + (3) \\
\hline 2019 & $3.3 \%$ & $3.3 \%$ & $3.3 \%$ & $3.3 \%$ & $3.3 \%$ \\
2020 & $-6.7 \%$ & $-6.7 \%$ & $-6.7 \%$ & $-6.7 \%$ & $-6.7 \%$ \\
2021 & $3.4 \%$ & $4.0 \%$ & $5.2 \%$ & $4.3 \%$ & $6.0 \%$ \\
2022 & $5.9 \%$ & $6.0 \%$ & $6.1 \%$ & $5.9 \%$ & $6.3 \%$ \\
2023 & $4.8 \%$ & $4.8 \%$ & $5.0 \%$ & $4.8 \%$ & $5.1 \%$ \\
2024 & $4.7 \%$ & $4.7 \%$ & $4.9 \%$ & $4.7 \%$ & $5.0 \%$ \\
2025 & $4.3 \%$ & $4.4 \%$ & $4.5 \%$ & $4.3 \%$ & $4.6 \%$ \\
2026 & $4.0 \%$ & $4.1 \%$ & $4.3 \%$ & $4.0 \%$ & $4.4 \%$ \\
2027 & $3.6 \%$ & $3.7 \%$ & $3.9 \%$ & $3.7 \%$ & $4.0 \%$ \\
2028 & $3.3 \%$ & $3.4 \%$ & $3.6 \%$ & $3.4 \%$ & $3.7 \%$ \\
2029 & $3.3 \%$ & $3.4 \%$ & $3.5 \%$ & $3.3 \%$ & $3.6 \%$ \\
2030 & $3.4 \%$ & $3.5 \%$ & $3.6 \%$ & $3.4 \%$ & $3.7 \%$ \\
\hline
\end{tabular}

Source: GEIH and authors' calculations.

Table 7 shows the actual GDP growth projections linked to the DID reforms.

Table 7. GDP growth projections from CGE simulation digital infrastructure development (DID) reforms.

\begin{tabular}{ccccc}
\hline & BAU & Digital Infrastructure (1) & Growth High Skill Labor (2) & (1) + (2) \\
\hline 2019 & $3.3 \%$ & $3.3 \%$ & $3.3 \%$ & $3.3 \%$ \\
2020 & $-6.7 \%$ & $-6.7 \%$ & $-6.7 \%$ & $-6.7 \%$ \\
2021 & $3.4 \%$ & $5.7 \%$ & $3.4 \%$ & $5.8 \%$ \\
2022 & $5.9 \%$ & $6,2 \%$ & $5.9 \%$ & $6.3 \%$ \\
2023 & $4.8 \%$ & $5.3 \%$ & $4.9 \%$ & $5.4 \%$ \\
2024 & $4.7 \%$ & $5.2 \%$ & $4.7 \%$ & $5.3 \%$ \\
2025 & $4.3 \%$ & $4.8 \%$ & $4.4 \%$ & $4.9 \%$ \\
2026 & $4.0 \%$ & $4.5 \%$ & $4.1 \%$ & $4.7 \%$ \\
2027 & $3.6 \%$ & $4.2 \%$ & $3.7 \%$ & $4.3 \%$ \\
2028 & $3,3 \%$ & $3.9 \%$ & $3.4 \%$ & $4.0 \%$ \\
2029 & $3.3 \%$ & $3.8 \%$ & $3.4 \%$ & $4.0 \%$ \\
2030 & $3.4 \%$ & $3.9 \%$ & $3.5 \%$ & $4.0 \%$ \\
\hline
\end{tabular}

Source: GEIH and authors' calculations.

Even when we extended the horizon of the analysis by five and ten years, there was no impact of either GVC or DID reforms on the Gini coefficient. The growth effect and impact on formal employment generation from the JET reform comes mostly from the reduction in logistics costs and is felt most strongly as a half a percentage point growth rate long terms increase when all three reforms are combined as it can be seen in Figure 7. Figure 8 shows that this translates into more than forty thousand additional yearly formal jobs in the span of a decade attributable to reductions in tariffs, logistics costs and FDI barriers through GVC integration.

The formal employment growth boost was particularly produced by the reforms captured by the combination of digital infrastructure and skill formation policies as reflected in Figures 9 and 10. Figure 9 shows a half percentage impact on the growth rate of GDP for a decade primarily through digital infrastructure and this translates into job creation to the tune of over fifty thousand formal positions per year per for a decade. This is not a negligible impact but in aggregate terms does not puta dent in the degree of informality in Colombian labor markets. 


\section{Differences from BAU}

3.0

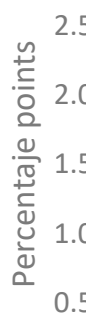

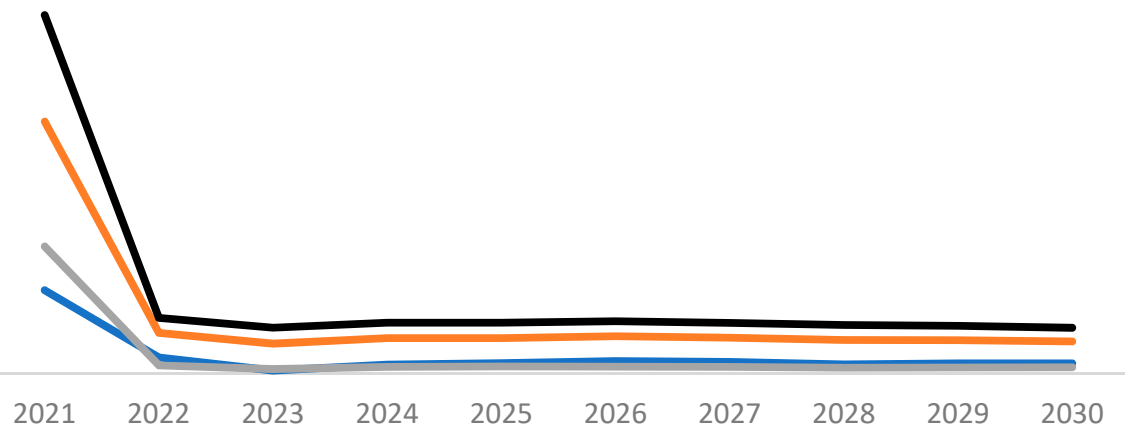

2021

Unilateral cut of tariffs (1)

Lower logistic costs (2)

$\longrightarrow$ FDI growth $10 \%(3)$

All (1) +(2)+(3)

Figure 7. Growth Effects of JET Reforms. Source: Authors' calculations.

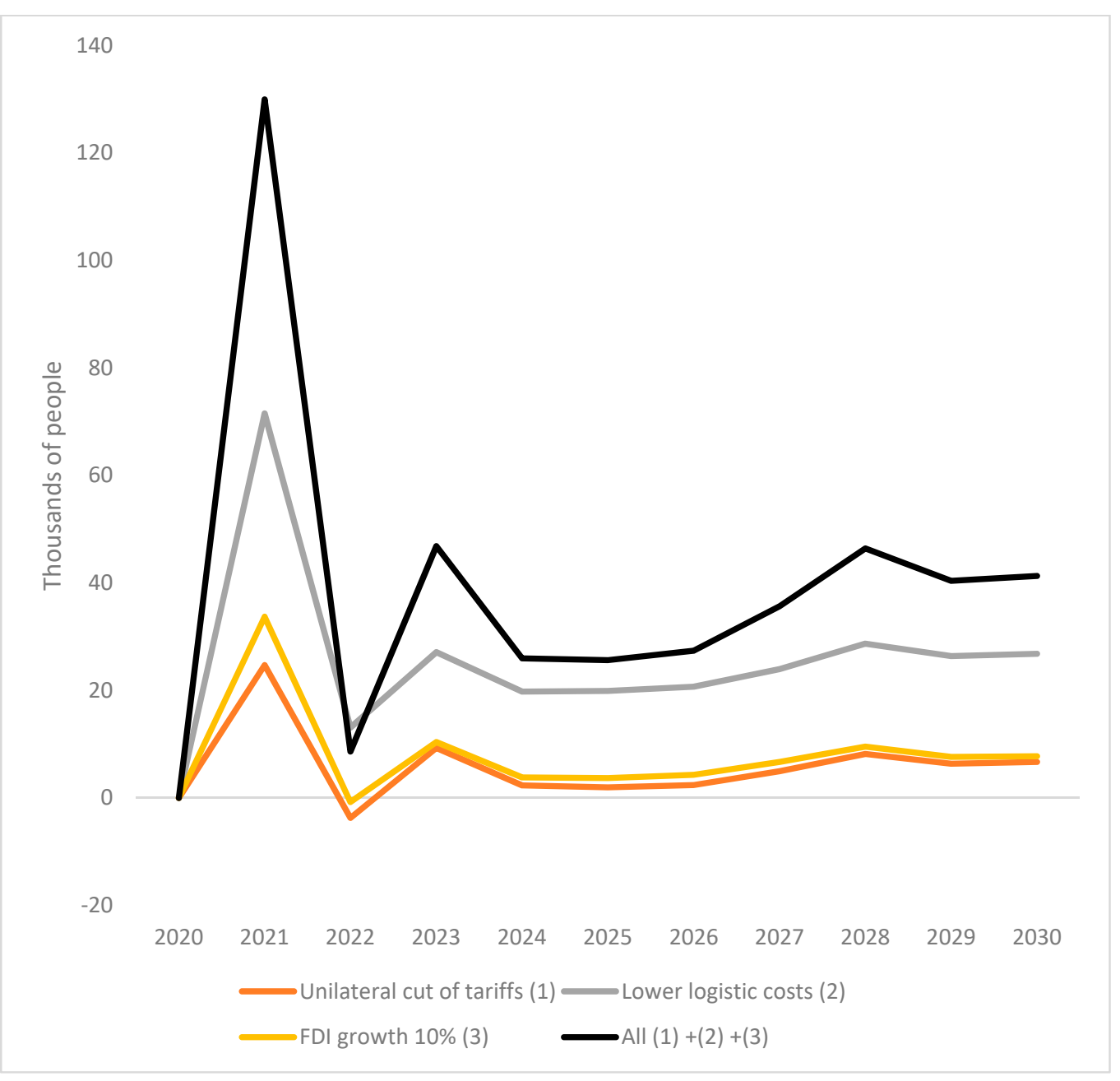

Figure 8. Employment Generation from JET Reforms. Source: Authors' calculations. 


\section{Differences from BAU}

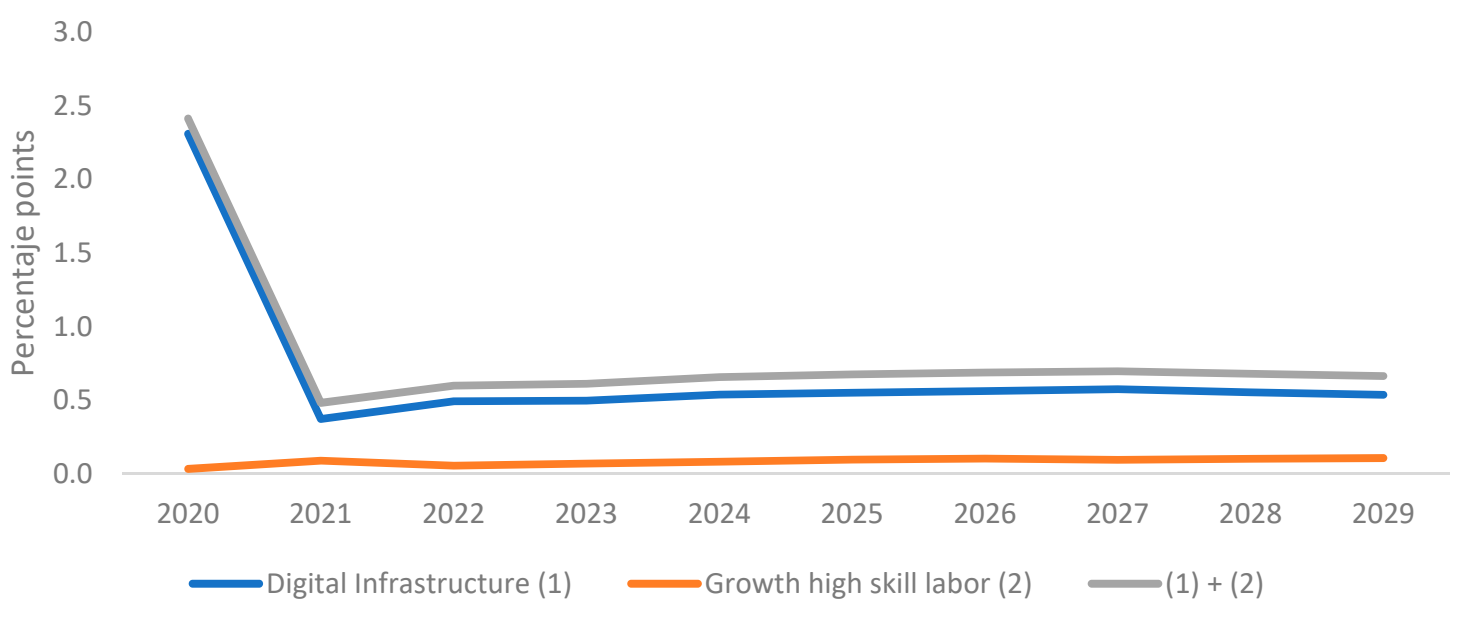

Figure 9. GDP Growth Effects of Digital Infrastructure Development. Source: Authors' calculations.

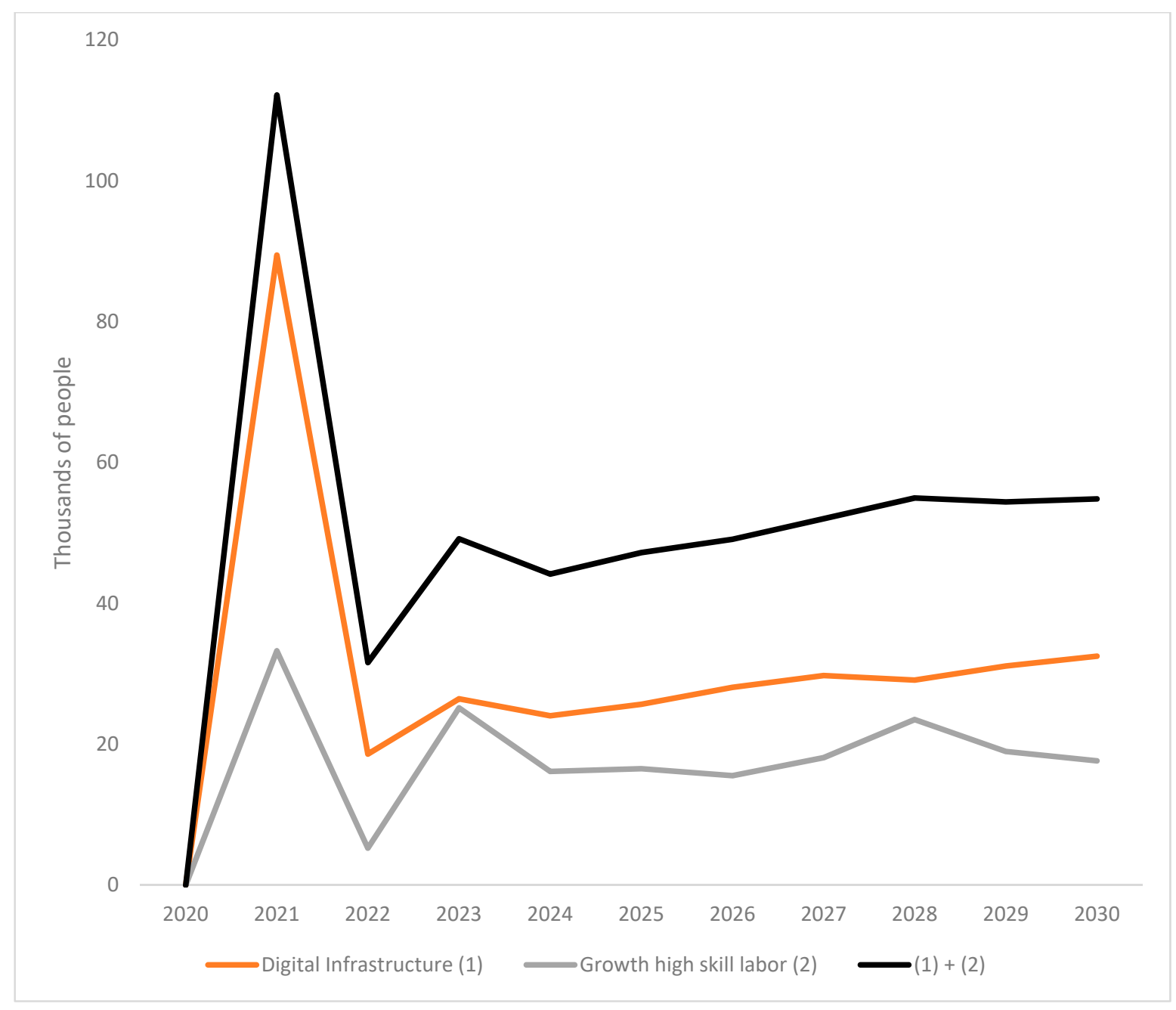

Figure 10. Employment Generation Effects from Digital Infrastructure Development. Source: Authors' calculations. 
On balance, there was a modest effect of DID on poverty reduction, as indirect job creation effects are felt through multiplier effects that manifest in growth and employment as seen in Table 8. The DID employment multiplier is lower than the growth of high skill labor employment multiplier and this provides evidence that lack of human capital rather than access to telework is a binding constraint for workers from poor households to formal employment opportunities, which per Figure 10 are limited on aggregate to around 50,000 per year and most likely benefiting skilled workers in the upper portions of the wealth and human capital distribution.

Table 8. Employment effects from digital infrastructure development (DID) reforms.

\begin{tabular}{ccccc}
\hline & & $\begin{array}{c}\text { Digital Infrastructure } \\
\mathbf{( 1 )}\end{array}$ & $\begin{array}{c}\text { Growth High Skill } \\
\text { Labor (2) }\end{array}$ & (1) + (2) \\
\hline \multicolumn{2}{c}{ Employment multiplier } & 2.1 & 2.6 & 2.3 \\
\hline \multirow{2}{*}{ Employment } & Direct & 1068 & 658 & 1794 \\
& Indirect & 970 & 411 & 1380 \\
\hline \multirow{2}{*}{ Employment } & Direct & $52.4 \%$ & $61.5 \%$ & $56.5 \%$ \\
& Indirect & $47.6 \%$ & $38.5 \%$ & $43.5 \%$ \\
\hline
\end{tabular}

Source: GEIH and authors' calculations.

The overall impact of JET through GVC integration on GDP and formal jobs generated no discernible impact on lowering poverty nor inequality, as indicated in Table 9 . While it has been indicated that there was formal job creation, it appears that the benefits did not reach the most vulnerable and poor, who did not possess the human capital to access those new employment opportunities. In the future, further efforts will be needed to widen skill acquisition among the population segments that need to avail themselves of those job options to escape poverty and close the yawning inequality gaps in the wake of the pandemic.

Table 9. Microsimulation impact on poverty and inequality Global Value Chain (GVC) reforms.

\begin{tabular}{|c|c|c|c|c|c|c|}
\hline & \multicolumn{6}{|c|}{ Panel A: 2025} \\
\hline & & Baseline & $\begin{array}{l}\text { Unilateral cut of } \\
\text { tariffs }(1)\end{array}$ & $\begin{array}{l}\text { Lower logistic } \\
\text { costs }(2)\end{array}$ & $\begin{array}{l}\text { FDI growth } 10 \% \\
\text { (3) }\end{array}$ & All $(1)+(2)+(3)$ \\
\hline \multirow{4}{*}{$\begin{array}{c}\text { Poverty } \\
\text { headcount }\end{array}$} & Extreme poverty & 6.28 & 5.94 & 6.22 & 6.23 & 5.84 \\
\hline & Total poverty & 21.95 & 20.65 & 21.71 & 21.79 & 20.31 \\
\hline & Gini & 51.29 & 51.09 & 51.29 & 51.28 & 51.05 \\
\hline & \multicolumn{6}{|c|}{ Panel B: 2030} \\
\hline \multirow{5}{*}{$\begin{array}{c}\text { Poverty } \\
\text { headcount }\end{array}$} & Extreme poverty & 5.19 & 4.97 & 5.15 & 5.16 & 4.94 \\
\hline & Total poverty & 17.79 & 16.80 & 17.58 & 17.68 & 16.57 \\
\hline & Gini & 50.45 & 50.44 & 50.46 & 50.44 & 50.45 \\
\hline & & \multicolumn{5}{|c|}{ Differences from baseline } \\
\hline & & Baseline & $\begin{array}{l}\text { Unilateral cut of } \\
\text { tariffs (1) }\end{array}$ & $\begin{array}{l}\text { Lower logistic } \\
\text { costs }(2)\end{array}$ & $\begin{array}{l}\text { FDI growth } 10 \% \\
\text { (3) }\end{array}$ & All $(1)+(2)+(3)$ \\
\hline \multirow{4}{*}{$\begin{array}{c}\text { Poverty } \\
\text { headcount }\end{array}$} & Extreme poverty & 6.28 & -0.336 & -0.056 & -0.046 & -0.438 \\
\hline & Total poverty & 21.95 & -1.297 & -0.237 & -0.157 & -1.633 \\
\hline & Gini & 51.29 & -0.205 & -0.005 & -0.015 & -0.248 \\
\hline & \multicolumn{6}{|c|}{ Panel B: 2030} \\
\hline \multirow{3}{*}{$\begin{array}{c}\text { Poverty } \\
\text { headcount }\end{array}$} & Extreme poverty & 5.19 & -0.220 & -0.040 & -0.030 & -0.254 \\
\hline & Total poverty & 17.79 & -0.987 & -0.207 & -0.107 & -1.218 \\
\hline & Gini & 50.45 & -0.013 & 0.007 & -0.013 & 0.002 \\
\hline
\end{tabular}

Source: GEIH and authors' calculations.

The overall impact on GDP of DID through formal employment generation created a discernible effect of lowering poverty, as indicated in Table 10, but the impact on inequality ran in the opposite direction, most likely due to a rise in the skill premium associated with 
digital infrastructure development as more jobs become amenable to telework and distance learning becomes more feasible. In Panel B, the Gini coefficient was projected to become slightly larger by 2030 although both extreme poverty and total poverty were forecasted to diminish.

Table 10. Microsimulation impact on poverty and inequality digital infrastructure development (DID) reforms.

\begin{tabular}{|c|c|c|c|c|c|}
\hline & & Baseline & $\begin{array}{c}\text { Digital } \\
\text { Infrastructure (1) }\end{array}$ & $\begin{array}{c}\text { Growth High } \\
\text { Skill Labor (2) }\end{array}$ & $(1)+(2)$ \\
\hline & & & Pane & 2025 & \\
\hline \multirow{4}{*}{ Poverty headcount } & Extreme poverty & 6.28 & 5.79 & 6.24 & 5.72 \\
\hline & Total poverty & 21.95 & 20.06 & 21.72 & 19.79 \\
\hline & Gini & 51.29 & 50.97 & 51.17 & 50.80 \\
\hline & & \multicolumn{4}{|c|}{ Panel B: 2030} \\
\hline \multirow{6}{*}{ Poverty headcount } & Extreme poverty & 5.19 & 4.88 & 5.20 & 4.96 \\
\hline & Total poverty & 17.79 & 16.30 & 17.82 & 16.38 \\
\hline & Gini & 50.45 & 50.45 & 50.45 & 50.48 \\
\hline & & \multicolumn{4}{|c|}{ Differences from baseline } \\
\hline & & Baseline & $\begin{array}{c}\text { Digital } \\
\text { Infrastructure (1) }\end{array}$ & $\begin{array}{c}\text { Growth High } \\
\text { Skill Labor (2) }\end{array}$ & $(1)+(2)$ \\
\hline & & & Pane & 2025 & \\
\hline \multirow{4}{*}{ Poverty headcount } & Extreme poverty & 6.28 & -0.486 & -0.036 & -0.556 \\
\hline & Total poverty & 21.95 & -1.887 & -0.227 & -2.157 \\
\hline & Gini & 51.29 & -0.325 & -0.125 & -0.495 \\
\hline & & \multicolumn{4}{|c|}{ Panel B: 2030} \\
\hline \multirow{3}{*}{ Poverty headcount } & Extreme poverty & 5.19 & -0.310 & 0.010 & -0.230 \\
\hline & Total poverty & 17.79 & -1.487 & 0.033 & -1.407 \\
\hline & Gini & 50.45 & -0.003 & -0.003 & 0.027 \\
\hline
\end{tabular}

Source: GEIH and authors' calculations.

The fact that there is a slight rise in inequality is indicative that the wage gap rises and that the winners from the formal employment opportunities are in the upper portion of the income distribution while the losers are in the lower echelons. For the JET reforms of GVC and DID to generate inclusive growth reflected in improvement in the Gini coefficient, there would have to be a parallel process whereby poorer households are able to accumulate the human capital they need to be able to access the higher quality formal jobs created by the reforms through linkages to global value chains and distance learning or telework. The contribution of these results is to highlight that even in the long run outward-oriented policies require complementary human capital accumulation to lower inequality through formal job access expansion for the poor.

\section{Robustness and Sensitivity Analysis of the Results}

In this section, we report on the sensitivity analyses to ascertain the robustness of our results. In relation to the findings from the microsimulations, the results from the model are robust, as they converge with negligible differences after 30 random iterations with a stochastic independently identically distributed shock. In relation to the results from the CGE model, the robustness is somewhat more tentative due to the fact that the elasticities were estimated but did not yield confidence intervals in the conventional sense. Having said this, the results presented in this paper coincide qualitatively and quantitatively with results presented elsewhere in the literature in related simulations. In particular, the elasticities that were input parameters for the model were estimated for Colombia and were subject to sensitivity analyses. For example, Hernández (2014) reports elasticities for exports and imports as well as foreign direct investment and the robustness of CGE 
simulations to parametric variations within certain ranges. At the same time, Bussolo et al. (2011) and Hernández (2012) report the robustness of CGE simulations with elasticities for labor supply and labor demand subject to shocks in policy parameters for sensitivity analysis when payroll taxes and minimum wages are reduced.

First, the fact that the microsimulations originated from randomized iterations that converged as differences became negligible and that we could confirm the robustness of the findings is indeed key. Second, the fact that the elasticities were estimated from an evidence base constructed from administrative data coming from the Government of Colombia lends credence to the model. In other words, our parameters originated from elasticities that had a solid track record and delivered robust results consistently. Finally, the objective of the CGE and micro-simulation exercises was to understand the effects of policy scenarios related to GVCs and DID that are reasonable and sensible for the government to contemplate in the post-COVID agenda. We did not engage in creating dozens of different policy scenarios to ascertain sensitivity but rather focused on those that are reasonable and relevant, as we have done.

In other words, we have a CGE model and a microsimulation module with an optimization framework, options, and decisions based on solid evidence of estimated elasticities, then we opened the sensitivity of the policy scenarios enough so that we could offer sufficient alternative scenarios to the government in a suite of choices to select optimally. Moreover, finally, we allowed for the microsimulations to be subject to random perturbations via iterations of stochastic independent identically distributed shocks and verified convergence by negligible differences in the outcomes of interest after 30 rounds. With this methodology, we obtained estimates that are both relevant and precise for policy formulation.

\section{Concluding Remarks}

We proposed an analytical framework that brings together the macroeconomic structure of a CGE (also known as Mecepes) developed by DNP-DEE. The labor market components of that model are described by Bussolo et al. (2011), and a GTAP module was also included for the external sector since the policy changes included customs enhancements, tariff declines, and lower barriers to FDI inflows. We used microsimulations in order to assess the distributional and poverty impacts of changes in wages and employment under different scenarios based on labor demand and supply consequences of JET reforms to boost GVC integration and policies to promote DID. In addition, the modelling of GVCs both in relation to trade flows with the rest of the world and potential backward linkages with other local firms required the addition of an open-economy module based on GTAP tailored for the Colombian economy. A complementary component of the analysis determined the impact of DID through both telework expansion and further virtual education opportunities, in particular distance-learning vocational training. We also brought to bear into the analysis the socioeconomic profile of workers likely to benefit and lose from the job creation or destruction following such GVC and DID policy reforms.

Some international channels that impact the Colombian economy include a collapse of exports (most notably with oil prices hitting their lowest level in 40 years and also tourism shut down), drying up of external finance with rating agency downgrading, drastic drop in remittance inflows (due to unemployment faced by migrant workers based abroad who come mostly from the coffee growing region), and disintegration of GVCs diluting intermediate input trade. This disintegration is due to the rippling effects of sequential lockdowns globally, which have wrecked supply chains that rely importantly on precise just-in-time (JIT) delivery and strict total quality control (TQM) management that could not be maintained as COVID-19 disseminated to more and more countries. Such disruptions may actually yield new opportunities now to new countries as the GVCs gradually rebuild and consider a new configuration of suppliers and provider nations for key components. ${ }^{15}$

Other effects that impinge heavily on poor households in Colombia include not only lower earnings due to informal worker status (no benefits or safety nets) and job loss 
(no telework alternatives with most workers hurt by the digital divide) but also rising consumption basket prices (especially food) due to limited competition (SMEs shutting down and no perishable imports). The increase in monopoly rents through higher prices may not be a transitory effect and needs to be incorporated as we model the evolution of real income for the poor transitioning out of the COVID-19 crisis. As GVC integration stimulates international trade, it not only could help the poor on the wage growth side through new-more productive-indirect jobs but also could help lower the cost of living.

Therefore, the JET policies we are considering can be particularly relevant in the challenging environment brought about by the pandemic. The application of the CGE framework incorporating microsimulation and GTAP modules generates insights on the technical merits and limitations of the proposed methodology. The data requirements of workforce information are substantial and were met in the case of Colombia but need to be checked on a case-by-case basis for replicability in other contexts. Finally, our discussion of the implementation and evaluation dimensions of JET will include the refinement of the policy questions that the strategy tackles and the depth of policy recommendations that emanate from the job creation framework (in our case GVC and DID driven). This analytical approach can contribute much added value, especially when applied in a context of a crisis, such as the COVID-19 pandemic, that exacerbates the employment needs of the poor and vulnerable.

Our analysis included job creation by firms linked to GVCs. In addition to this direct formal employment possibly associated with the JET strategy, a worthwhile extension of the analysis would be to explore whether the demand for local inputs and intermediate services by these firms creates jobs indirectly. The analysis as a whole included general equilibrium effects such as multiplier effects from input-output matrices and the income effects across sectors for different segments of the population. For example, the multiplier effect from the DID policy scenario encompassed both direct and indirect job creation through the infrastructure investment as well as the incidence of both telework and distance learning, impacting formal employment over the 10-year horizon (Table 8). These impacts translate into more tangible poverty reduction achievements per Table 10, compared with what can be gained through GVC policies alone when DID reforms are implemented (Table 9), but they are still limited in the context of the needs created by the massive COVID-19 employment shock. The results illustrate the patent need of complementary human capital investments to make new formal jobs created through JET strategies accessible to the most vulnerable populations if poverty and inequality reductions so sorely needed in the wake of the COVID-19 pandemic are to be achieved in developing countries.

Author Contributions: All authors have contributed to the conceptualization, methodology, software, validation, data curation, computable general equilibrium analysis, microsimulation, original draft preparation, review and edition, visualization and supervision. All authors have read and agreed to the published version of the manuscript.

Funding: Kugler acknowledges research funding from the World Bank for this paper.

Data Availability Statement: The underlying data used for this study are available from the Colombian National Statistical Agency (Departamento Nacional Administrativo de Estadística-DANE at http:/ / www.dane.gov.co/index.php/en accessed on 15 March 2021.

Conflicts of Interest: The authors declare no conflict of interest.

\section{Notes}

Similar findings are reported by Shepherd (2013) and Yane (2019).

Agriculture, manufacturing (apparel, automotive, IT hardware), and business services for the following types of work: (1) small scale, household-based work; (2) low-skilled, labor intensive work; (3) moderate skilled, varied labor intensities work; (4) highskilled, technology intensive work; and (5) knowledge-intensive. See Villamil and Hernández (2016)

3 An index based on factor analysis with six components was conducted: information and communication technologies' (ICT) skills; readiness to learn and creative problem solving; managing and communication; self-organization; marketing and accounting; and science, technology, engineering, and mathematics (STEM)-quantitative skills. 
Kugler and Kugler (2009); Bussolo et al. (2011); Kugler et al. (2017) and Organization for Economic Cooperation and Development (2019).

$5 \quad$ Kugler et al. (2020) analyze the impact on the future of work in Colombia of robot adoption in the U.S.

See Kugler and Neusser (1998) for evidence of the influence of access to finance as a key determinant of productivity growth.

See for example Eslava et al. (2010), who show how both the tariff average and variance decline linked to higher manufacturing productivity.

8 See for example Bettinger et al. (2019) and Kugler et al. (2022).

9 The groups are skilled formal adult, skilled informal adult, unskilled formal adults, unskilled informal adults, skilled formal youth, skilled informal youth, unskilled formal youth, and unskilled informal youth.

See Bussolo et al. (2011) for modeling and estimation details of the flow parameters for formal-informal labor market transitions. These policies were spelled out in a technical report by an expert commission: Presidencia de la República de Colombia (2018).

The lockdown in Colombia started on 24 March 2020 and continues to be active at the time of writing this paper. However, there have been three successive re-openings of the economy every two weeks since the first one on 13 April 2020. There is a great uncertainty about the end of the lockdown and whether there will be additional re-opening stages or, rather, closures or partial closures. For this reason, we more simply assume a 3 month period of lockdown, after which the economy reopens gradually.

13 Furthermore, $\theta$ defines the allocation rule within each household $\mathrm{h}$ that aggregates all incomes generated by its members. We follow the widely-used unitary rule (due to the lack of a rigorous alternative; see Browning et al. 2014). Under this cooperative intrahousehold allocation model, all income sources are shared among members according to their needs (on a per capita basis or adjusted by equivalence scales). This is a convenient assumption but not necessarily realistic and as such, this first approximation model may underestimate the pandemic's effects on poverty.

14 In the case of extreme poor, simulations raise the headcount of 3.5 million by 1.5 and 3.7 million, depending on the income loss considered, 50 or 100 percent, respectively.

15 A factor determining whether Colombian suppliers can latch onto service sector supply chains will be the quality of digital infrastructure, determining the reliability of telecommunications.

\section{References}

Barrientos, Stephanie, Gary Gereffi, and Arianna Rossi. 2011. Economic and Social Upgrading in Global Production Networks: A New Paradigm for a Changing World. International Labour Review. 150: 319-340. [CrossRef]

Bechichi, Nagui, Stephanie Jamet, Gustave Kenedi, Robert Grundke, and Mariagrazia Squicciarini. 2019. Occupational Mobility, Skills and Training Needs. Technology and Innovation Policy Papers. Paris: OECD Science, Organisation of Economic Cooperation and Development.

Bettinger, Eric, Michael Kremer, Maurice Kugler, Carlos Medina, Christian Posso, and Juan Saavedra. 2019. School Vouchers, Labor Markets and Vocational Education. Borradores de Economia No. 1087. Bogotá: Banco de la Republica.

Browning, Martin, Pierre-Andre Chiappori, and Yoram Weiss. 2014. Economics of the Family. Cambridge: Cambridge University Press.

Buitrago, Maria, and Jose León. 2015. Efectos de la inversión extranjera directa sobre el crecimiento económico en Colombia: Evidencia empírica 2000-10. Apuntes del CENES 34: 63-91. [CrossRef]

Bussolo, Maurizio, Maurice Kugler, and Denis Medvedev. 2011. Informality and Labor Market Policies in Colombia. Working Paper. Bogotá: DNP, Fedesarrollo, and World Bank.

Calvo, Guillermo. 1983. Staggered prices in a utility-maximizing framework. Journal of Monetary Economics 12: 383-98. [CrossRef]

Criscuolo, Chiara, and Jonathan Timmis. 2017. The Relationship Between Global Value Chains and Productivity. International Productivity Monitor 32: 61-83.

Cuesta, Jose, and Juliette Pico. 2020. COVID-19 Affects Everyone But Not Equally: The Gendered Poverty Effects of the COVID-19 Pandemic in Colombia. Washington: World Bank, Poverty and Equity, Mimeo.

D'Adamo, Idiano, and Paolo Rosa. 2020. How Do You See Infrastructure? Green Energy to Provide Economic Growth after COVID-19. Sustainability 21: 4738. [CrossRef]

Departamento Administrativo Nacional de Estadistica. 2018. Boletín Técnico: Encuesta Nacional de Presupuestos de los Hogares (ENPH) 2016-2017. Bogotá: DANE.

Eaton, Jonathan, Marcela Eslava, Maurice Kugler, and James Tybout. 2008. The Margins of Entry into Export Markets: Evidence from Colombia. In The Organization of Firms in a Global Economy. Edited by Elhanan Helpman, Dalia Marin and Thierry Verdier. Cambridge: Harvard U. Press, pp. 1453-98.

Echavarría, Juan, and George Zodrow. 2005. Impuestos a las utilidades e inversión extranjera directa en Colombia. Documento de Trabajo del Banco de la República 25. Bogotá: Banco de la Republica.

Echavarría, Juan, Iader Giraldo, and Fernando Jaramillo. 2019. Cadenas globales de valor, crecimiento y protección arancelaria en Colombia. Borradores de Economía 1080. Bogotá: Banco de la Republica.

Esguerra, Maria, and Sergio Ulloa. 2016. Colombia, por Fuera las Cadenas Globales de Valor: ¿Causa o Sintoma del Bajo Desempeño Exportador? Borradores de Economía No. 966. Bogotá: Banco de la República. 
Eslava, Marcela, John Haltiwanger, Adriana Kugler, and Maurice Kugler. 2004. The Effects of Structural Reforms on Productivity and Profitability Enhancing Reallocation: Evidence from Colombia. Journal of Development Economics 75: 333-71. [CrossRef]

Eslava, Marcela, John Haltiwanger, Adriana Kugler, and Maurice Kugler. 2010. Factor Adjustments after Deregulation: Panel Plant Evidence from Colombia. Review of Economics and Statistics 92: 378-91. [CrossRef]

Eslava, Marcela, John Haltiwanger, Adriana Kugler, and Maurice Kugler. 2013. Trade Reforms and Market Selection: Evidence from Manufacturing Plants in Colombia. Review of Economic Dynamics 16: 135-58. [CrossRef]

Farole, Thomas. 2016. Do global value chains create jobs? Impacts of GVCs depend on lead firms, specialization, skills, and institutions. IZA World of Labor 2016: 291.

Garavito, Aaron, Ana Iregui, and Maria Ramírez. 2012. Inversión Extranjera Directa en Colombia: Evolución reciente y marco normativo. Borradores de Economía 713: 1-63.

Garavito-Acosta, Aaron, Ana Iregui-Bohórquez, and Maria Ramírez-Giraldo. 2013. Inversión extranjera directa en Colombia: Evolución, indicadores y determinantes por firma. In Inversión Extranjera Directa en Colombia: Evolución, Indicadores y Determinantes por Firma. Bogota: Banco de la Republica, Chapter 3.

Grundke, Robert, Stephanie Jamet, Margarita Kalamova, Francois Keslair, and Mariagrazia Squicciarini. 2017. Skills and Global Value Chains: A Characterization. Technology and Industry Working Papers 2017/05. Paris: OECD Science. OECD.

Gyeke-Dako, Agyapomaa, Abena Oduro, Ebo Turkson, Priscilla Twomasi Baffour, and Emmanuel Nii Abbey. 2017. Ghana's Participation in Global Value Chains: The Employment Effects. Zurich: Swiss National Science Foundation.

Haltiwanger, John, Adriana Kugler, Maurice Kugler, Alejandro Micco, and Carmen Pagés. 2004. Effects of Tariffs and Real Exchange Rates on Job Reallocation: Evidence from Latin America. Journal of Policy Reform 7: 189-208. [CrossRef]

Hernández, Gustavo. 2012. Payroll Taxes and the Labor Market: A Computable General Equilibrium Analysis. Latin American Journal of Economics 49: 99-123.

Hernández, Gustavo. 2014. Una revisión de los efectos del Tratado de Libre Comercio entre Colombia y Estados Unidos. Lecturas de Economia 80. [CrossRef]

Hernández-Diaz, Gustavo, Luis Quintero, and Julian Villamil. 2019a. Generacion de Empleos y Clusteres. Archivos de Económia. Number 502. Bogotá: Departamento Nacional de Planeación.

Hernández-Diaz, Gustavo, Luis Quintero, and Julian Villamil. 2019b. La Estructura Sectorial de Colombia: Un Análisis Insumo-Producto. Archivos de Económia. Number 503. Bogota: Departamento Nacional de Planeación.

Hollweg, Claire. 2019. Global value chains and employment in developing economies. In GVC Development Report: Technological Innovation, Supply Chain Trade, and Workers in a Globalized World. Washington, DC: World Bank, Chapter 3.

International Development Association. 2019. IDA19 Special Theme: Jobs and Economic Transformation. Washington, DC: World Bank Group.

International Finance Corporation. 2020. The Impact of COVID-19 on Logistics. Washington, DC: World Bank Group.

Kugler, Adriana, and Maurice Kugler. 2009. The Labor Market Effects of Payroll Taxes: Evidence from Colombia. Economic Development and Cultural Change 56: 335-58. [CrossRef]

Kugler, Adriana, Maurice Kugler, and Luis Herrera. 2017. Do Payroll Tax Breaks Stimulate Formality? Evidence from Colombia's Reform. Economía 18: 1-40.

Kugler, Adriana, Maurice Kugler, Juan Saavedra, and Luis Herrera. 2022. Long-Term Education Consequences of Youth Vocational Training in Colombia: Impacts on Trainees, Their Relatives and Potential Mechanisms. The Journal of Human Resources 57: 178-216. [CrossRef]

Kugler, Adriana, Maurice Kugler, Laura Ripani, and Rodimiro Rodrigo. 2020. Impacts of U.S. Robots in the Tropics: Evidence from Colombian Labor Markets. NBER Working Paper No. 28034. Cambridge, MA: National Bureau of Economic Research.

Kugler, Maurice, and Eric Verhoogen. 2009. Plants and Imported Inputs: New Facts and Interpretation. American Economic Review 99: 501-7. [CrossRef]

Kugler, Maurice, and Eric Verhoogen. 2012. Prices, Plant Size, and Product Quality. Review of Economic Studies 79: 307-39. [CrossRef]

Kugler, Maurice, and Hillel Rapoport. 2007. International Labor and Capital Flows: Complements or Substitutes? Economics Letters 92: 155-62. [CrossRef]

Kugler, Maurice, and Howard Rosenthal. 2005. Checks and Balances: An Assessment of the Institutional Separation of Political Powers. In Institutional Reforms in Colombia. Edited by Alberto Alesina. Cambridge: MIT Press.

Kugler, Maurice, and Klaus Neusser. 1998. Manufacturing Growth and Financial Development: Evidence from OECD Countries. Review of Economics and Statistics 80: 628-46.

Kugler, Maurice, Thierry Verdier, and Yves Zenou. 2005. Organized, Crime, Corruption and Punishment. Journal of Public Economics 89: 1639-69. [CrossRef]

Kugler, Maurice. 2006. Spillovers from foreign direct investment: Within or between industries? Journal of Development Economics 80: 444-77. [CrossRef]

Kugler, Maurice. 2009. Factor Endowments and FDI. In Princeton Encyclopedia of the World Economy. Edited by Kenneth Reinert, Ramkishen Rajan, Amy Joycelyn Glass and Lewis Davis. Princeton: Princeton University Press.

Lamprea, Tania, Vanessa Ospina, Gustavo Hernández, and Aana Rivera. 2020. Una medida de los efectos potenciales del Covid-19 en el empleo: El caso de la política de aislamiento preventivo obligatorio en Colombia. In Archivos de Economía. Number 508. Bogota: Departamento Nacional de Planeacion. 
Maestosi, Paola, Maria Andreucci, and Paolo Civiero. 2021. Sustainable Urban Areas for 2030 in a Post-COVID-19 Scenario: Focus on Innovative Research and Funding Frameworks to Boost Transition towards 100 Positive Energy Districts and 100 Climate-Neutral Cities. Energies 14: 216. [CrossRef]

Marcolin, Luca, and Mariagrazia Squicciarini. 2018. Investing in Innovation and Skills: Thriving through Global Value Chains. Review of Economics and Institutions 9: 1-33. [CrossRef]

Melendez, Marcela, and Maria Jose Uribe. 2012. International Product Fragmentation and the Insertion of Latin America and the Caribbean in Global Production Networks: Colombian Case Study. IDB Working Paper No. IDB-WP-374. Washington, DC: Inter-American Development Bank.

Organization for Economic Cooperation and Development. 2019. Economic Studies of the OECD: Colombia 2019. Paris: Organization for Economic Cooperation and Development.

Pietrzak, Michal, Aleksandra Chiebicka, Pawel Kracinzky, and Agata Malak-Rawlikowska. 2020. Information Asymmetry as a Barrier in Upgrading the Position of Local Producers in the Global Value Chain-Evidence from the Apple Sector in Poland. Sustainability 12: 7857. [CrossRef]

Presidencia de la República de Colombia. 2018. Plan Nacional de Desarrollo 2018-22: Pacto por Colombia. Pacto por la Equidad (Ley 1955 de 2019). Bogotá: Government of Colombia.

Reina, Mauricio, Daniela Ospina, Sebastian Macias, and Camila Cortes. 2016. Impacto Económico de la Inversión Extranjera Directa en Colombia 2007-15. Bogotá: Fedesarrollo.

Shepherd, Ben. 2013. Global Value Chains and Developing Country Employment: A Literature Review. OECD Trade Policy Papers, No. 156. Paris: Organisation for Economic Cooperation and Development.

Shuzhong, Ma, Yinfeng Liang, and Hongsheng Zhang. 2019. The Employment Effects of Global Value Chains. Emerging Markets Finance and Trade 55: 2230-53.

United Nations. 2010. Integrating Developing Countries' SMEs into Global Value Chains. Geneva: United Nations Conference on Trade and Development, UNCTAD.

van de Walle, Dominique, and Kimberly Nead. 1995. Public Spending and the Poor: Theory and Evidence. Baltimore: Johns Hopkins University Press.

Villamil, Julian, and Gustavo Hernández. 2016. Encadenamientos, clústeres y flujos de trabajo en la economía colombiana. Ensayos sobre Política Económica 34: 51-65. [CrossRef]

Vos, Rob Enrique Ganuza, Samuel Morley, and Sherman Robinson. 2006. Who Gains from Free Trade? Export-led Growth, Income Distribution and Poverty in Latin America. London: Routledge.

World Bank Group. 2019. ABCs of IDA-Jobs and Economic Transformation. Washington, DC: World Bank Group.

World Bank. 2013. World Development Report: Jobs. Washington, DC: World Bank.

World Bank. 2020. World Development Report: Trading for Development in the Age of Global Value Chains. Washington, DC: World Bank.

Yane, Haruka. 2019. GVCs and labor markets. Asia-Pacific Journal of Regional Science 3: 177-200. [CrossRef] 